\title{
O princípio da igualdade no direito islâmico
}

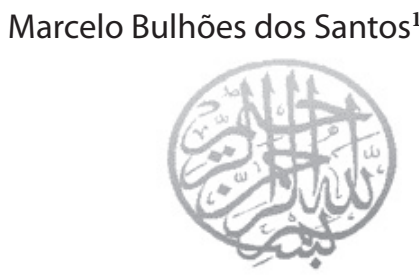

Em nome de Allah, o Clemente, o Misericordioso:

“[...] E dize: Senhor meu, acrescenta-me conhecimento."

Al Qur’an - قرآن, versículo 114 do XX capítulo.

\section{Resumo}

A justificativa teórica da investigação reside no fato de ser o Islam uma realidade cada vez mais corriqueira no mundo ocidental, aí incluído o Brasil. Ademais, é de se ressaltar o fato de que há, hoje, a necessidade de se compreender o outro, por necessidades inerentes ao ambiente multicultural. Assim, esta monografia propõe-se a investigar o significado e respectivo tratamento conferidos pelas comunidades muçulmanas a um instituto conhecido no Ordenamento Jurídico pátrio, qual seja o do princípio da igualdade. Verificar-se-á as especificidades como o Direito Islâmico trata a temática, a partir de uma perspectiva de bases teológicas. É de se mencionar que o progresso científico repercute no mundo jurídico, exigindo a criação e o desenvolvimento de novos mecanismos de atuação, regulamentação e controle. Esse processo envolve o debate e formulação axiológicos, os quais se vêem enriquecidos pela aproximação dos Sistemas Legais Ocidentais com o Direito Islâmico, em numerosos aspectos. Não se pretende, contudo, esgotar as maneiras de se abordar o assunto ou apresentar, em nenhum grau, uma comparação valorativa entre os institutos utilizados em sede de Direito Islâmico e os comumente adotados pelos Ordenamentos Jurídicos Ocidentais, notadamente os do ramo romano-germânico. O que se tenciona é analisar o princípio da igualdade

1 Monografia apresentada, em 2009, para a obtenção do Grau de Bacharel em Direito pela Faculdade de Ciências Jurídicas e Sociais do Centro Universitário de Brasília. Orientadora: Prof. ${ }^{a}$ Dr. ${ }^{a}$ Silvia Menicucci de Oliveira Selmi Apolinário. Monografia classificada em $3^{\circ}$ lugar no Concurso "Victor Nunes Leal" do Núcleo de Pesquisa e Monografia do Uniceub (2009). 
do modo como é aplicado no mundo islâmico, sob a perspectiva da lógica interna ao sistema estudado.

Palavras-chave: Islam. Char'ia. Direito e Moral. Teologia - aspectos sociais. Ética da Religião.

\section{Introdução}

Esta monografia ${ }^{2}$ tratará das perspectivas gerais a respeito da relação entre o Direito e a Ética Islâmicos, especialmente naquilo que concerne ao conceito axiológico de igualdade. Contudo, a pesquisa jurídica necessita de uma delimitação.

A abordagem que se seguirá neste trabalho será a histórico-teórica, que busca compreender o seu objeto de estudo, qualquer que seja, analisando os fenômenos pelos quais passa o objeto por meio da depreensão dos conseqüentes filosóficos de sua fenomenologia.

O escopo do Trabalho decorre, dentre outros fatores, de ser o Islam ${ }^{3}$ uma realidade cada vez mais corriqueira no mundo ocidental, aí incluído o

2 Nesta Monografia, foram utilizadas, como diretrizes metodológicas, as orientações contidas nos seguintes materiais: Manual de Elaboração de Monografia do Núcleo de Pesquisa da Faculdade de Ciências Jurídicas e Sociais do UniCEUB, com última edição no ano de 2005; Manual de Apoio aos Trabalhos Acadêmicos, elaborado para treinamento de usuários da Biblioteca João Herculino, prevalecendo este sobre o primeiro em caso de incongruências; e, as Orientações da Fundação Biblioteca Nacional a respeito da estrutura de um livro, disponível no sítio eletrônico <http://www.bn.br/portal/index.jsp?nu_pagina $=\mathbf{8}>$ conforme acesso aos 09 jun. 2009.

3 Neste trabalho, utilizar-se-á os termos originais da língua árabe em suas correspondentes transliterações fonéticas para o alfabeto latino, por serem as formas de uso consagrado nos meios acadêmicos internacionais. Especificamente, optamos por lançar mão do termo "Islam" por ser tradução mais fiel ao correspondente em língua árabe (اسلام) do que a forma tradicionalmente utilizada - Islã.

Explica-se: em língua árabe, todas as letras são pronunciadas, inclusive as consoantes isoladas, como o "min" - p (análogo à letra "m" em língua portuguesa) no caso da pronúncia da palavra "Islam". 
Brasil ${ }^{4}$. A vinda de muçulmanos para o país tomou fôlego a partir dos anos $1970^{5}$, após a guerra civil libanesa, as guerras árabe-israelenses e a ocupação de territórios palestinos. Nas últimas quatro décadas foram erguidas mesquitas e salas de orações no Paraná, em São Paulo, Mato Grosso, Minas Gerais e Rio de Janeiro. Ademais, desde a década de 1990 cresce a quantidade de brasileiros não árabes convertidos ao Islam. O português passou a ser adotado no sermão das sextas-feiras em comunidades muçulmanas como a do Rio de Janeiro. A renovada entrada dos convertidos nas comunidades religiosas criadas pelos imigrantes árabes mostra como elas passaram a integrar a paisagem religiosa da sociedade brasileira ${ }^{6}$. A realidade descrita atesta uma crescente aproximação entre o Islam e a sociedade brasileira. Surge, daí, a necessidade de analisar e melhor compreender o Islam, não apenas para afastar preconceitos, mas também para identificar elementos que possam vir a contribuir para o desenvolvimento do Ordenamento Jurídico brasileiro. Para tanto, é relevante compreender o significado de determinados princípios formadores do Islam. Este estudo tem como objetivo primário analisar o princípio da igualdade no Direito Islâmico.

A produção ${ }^{7}$ em língua portuguesa a respeito do tema abordado é escassa e, quando encontrada, tende ao superficialismo, sendo que se recorreu a alguns títulos em língua estrangeira para conseguir atingir os objetivos aos quais a presente obra se propõe.

${ }^{4}$ Com um percentual de 19,2\% da população mundial, os muçulmanos formam o maior grupo religioso do mundo, como se verifica em: FOMMENTI, Monsignor Vittorio. Annuario Pontifício 2008. Cidade do Vaticano: Libreria Editrice Vaticana, 2008.

5 Todas as referências a datas feitas neste trabalho levarão em conta o calendário cristão, correntemente adotado no Brasil, país da publicação do texto. Apenas para efeito de observação, o calendário islâmico se rege pelo ciclo lunar, tem 12 (doze) meses e começou a contar do ano de 622 (d.C.) do calendário cristão, data em que teria ocorrido a Hégira (i.e.: migração; diáspora) do Profeta Mohammad (comumente referido como Maomé), seus companheiros e seguidores da cidade de Meca para Medina, ambas no atual Reino da Arábia Saudita. O ano de 2009 corresponderia ao ano de 1430 da era islâmica.

${ }^{6}$ HILU R. PINTO, Paulo Gabriel. Toda forma de fé. Revista de História da Biblioteca Nacional, Rio de Janeiro: Fundação Biblioteca Nacional, n. 46, p. 27, ano 2009.

7 Além do trabalho de pesquisa junto à Biblioteca João Herculino do Centro Universitário de Brasília, onde pudemos encontrar escassa bibliografia acerca da temática em fulcro, procuramos verificar a existência de obras relacionadas nas Bibliotecas das redes coordenadas pelos sistemas do Senado Federal e do Palácio do Planalto, em Brasília/DF e na Fundação Biblioteca Nacional e Biblioteca Central da Pontifícia Universidade Católica, estando as duas últimas situadas na cidade do Rio de Janeiro/RJ. 
Representam exceções a esse quadro as seguintes obras, cujas referências completas podem ser encontradas na seção Referências Bibliográficas: "Islã clássico: itinerários de uma cultura"; a tradução de "O direito dos não-muçulmanos sob um Estado Islâmico"; "O Estado Islâmico e sua organização"10; bem como, o artigo científico "Do outro ao Diverso - Islão e Muçulmanos em Portugal: história, discursos, identidades"11.

As publicações em língua estrangeira que mais impactaram a presente monografia foram: "Enayat on Islam and Democracy"12; "Un análisis del derecho islâmico"13, de Jose Fernando García Cruz; e, "Freedom, Equality and Justice in Islam"14.

O Islam legal nunca foi, de todo, patrimônio dos profissionais do estudo teológico, tampouco tem se mantido restrito às Madrassas, ainda que estes tenham sido elementos determinantes de sua elaboração e preservação durante os últimos séculos do aporte de influências seculares sobre o ideário religioso islâmico ${ }^{15}$.

Os estudiosos ocidentais que se têm dedicado ao estudo do Direito Islâmico caracterizam-se, em geral, por um olhar desdenhoso, como que refletindo uma pretensa auto-suficiência dos Sistemas Jurídicos ocidentais, sem se dar conta de

8 DE SOUZA PEREIRA, Rosalie Helena (Organizadora). Islã clássico: itinerários de uma cultura. São Paulo: Perspectiva, 2007.

9 EL AED, Saleh Ibn Hussein. O Direito dos não-muçulmanos sob um Governo Islâmico. Trad. Sheikh Ali M. Abdune et Prof. a Soraia C. Mancilha. São Paulo: WAMY, 2003.

${ }^{10}$ ISBELLE, Sami Armed. O Estado Islâmico e sua Organização. Rio de Janeiro: Qualitymark, 2007.

${ }^{11}$ VAKIL, Abdoolkarim. Do outro ao Diverso - Islão e Muçulmanos em Portugal: história, discursos, identidades. Revista Lusófona de Ciência das Religiões, Lisboa: Edições Universitárias Lusófonas, n. 05, p. 283-312, ano 2004.

${ }^{12}$ HOOGARINSTITUTE.EnayatonIslamandDemocracy.Disponívelem: $<$ http://www.hoggar.org/index.php?option=com_docman\&task=doc_download\&gid=158\&Itemid=28 $>$. Aceso em : 3 jun. 2009.

${ }^{13}$ GARCÍA CRUZ, Jose Fernando, Un análisis del derecho islâmico, Cáceres: Universidad de Estremadura, Servicio de Publicaciones, 2004.

${ }^{14}$ KAMALI, Mohammad Hashim. Freedom, Equality and Justice in Islam. Islamic Texts Society: Cambridge, 2002.

${ }^{15}$ GARCÍA CRUZ, Jose Fernando. Opus citatum, p. 17. 
que muitos institutos utilizados nos Ordenamentos Jurídicos europeus e americanos advêm daquela origem ou sofreram influência do raciocínio jurídico islâmico clássico, como é o caso dos seguintes institutos (apenas para citar alguns): mandato de procuração ${ }^{16}$ (Common Law / ramo Romano-Germânico), Tribunal do Júri (Common Law / ramo Romano-Germânico), cessão de débito (Common Law / ramo Romano-Germânico), aval (Common Law / ramo Romano-Germânico), noções de motivo de força maior e de caso fortuito (Common Law / ramo Romano-Germânico), Protetorados/Fundações Pias (Common Law), bem como a reintegração de posse, nos casos de esbulho possessório (Common Law) ${ }^{17}$ etc.

Há de se levar em conta que sempre existiu um certo equívoco inerente à percepção ocidental, a qual pretendeu, no mais das vezes, aplicar seus parâmetros culturais aos outros. Essa própria alteridade torna inválida e estéril a unilateralidade da reflexão, por não prever que qualquer intenção de se analisar algum assunto a partir de um olhar que dispõe o próprio ponto de vista do observador como referente absoluto conduzirá ao fracasso.

Não haverá, por meio do presente trabalho, qualquer intenção de limitar a análise no sentido de realizar uma comparação valorativa com os institutos presentes nos Ordenamentos Jurídicos Ocidentais, utilizando-se por base a realidade acadêmica brasileira. Adiantamos que não será este o objetivo da presente monografia, mesmo porque o debate entre diferentes culturas em um ambiente democrático traz a necessidade de se reconhecer e tratar diferentes grupos como iguais, exigindo que as instituições públicas (inclusive no campo do debate educacional, acadêmico) reconheçam e respeitem as especificidades culturais. Esta exigência de reconhecimento de certas peculiaridades é compatível com um universalismo que tem a cultura valorizada pelos indivíduos como parte dos seus interesses fundamentais.

\footnotetext{
${ }^{16}$ Há que se distinguir a figura do nuntio (mensageiro) que já existia nas origens do Direito Romano.

${ }^{17}$ BADR, Gamal Moursi. Islamic Law: its relations to other Legal Systems. The American Journal of Comparative Law, n. 26, p. 187-198, ano 1977;

MAKDISI, John A. The Islamic Origins of the Common Law. North Carolina Law Review, n. 77, p. 1635-1739, ano 1998.
} 
Nessa perspectiva, assume relevo a questão da identidade. Charles Taylor afirma que a identidade é dialogicamente construída, como resultado das relações humanas, incluindo o próprio diálogo com os outros. Pode-se falar, ainda, em identidades individuais, ou seja, aquelas que são especificamente do self, que se descobrem em si ${ }^{18}$.

Pode-se dizer que a identidade se afirma em duas esferas: o indivíduo rodeado de outros indivíduos e os povos detentores de cultura rodeados de outros povos. Tal como os indivíduos, um povo deve ter atenção à sua cultura.

A constante necessidade de se adequar os diplomas legais a uma realidade social complexa poderia ser evitada pela análise atenta do modo como os princípios que balizam a criação das normas jurídicas são tratados em outros países com dimensões vastas e diversidade cultural, como é o caso do Brasil e de países do mundo islâmico ${ }^{19}$, que têm africanos, árabes, pashtuns, farsis, uzbeques, indianos, indonésios, turcos e muitos outros convivendo num verdadeiro melting pot ${ }^{20}$ cultural.

A investigação da formação do conceito do princípio da igualdade no Islam pode, assim, contribuir à formulação axiológica no Sistema Legal brasileiro. Neste particular, observa-se que o Direito no Brasil desenvolveu-se em grande parte dependente de um diálogo com os demais Ordenamentos Jurídicos do ramo romano-germânico. Todavia, deve-se indagar se a importação de modelos pré-concebidos, eurocêntricos, alcançaria os mesmos resultados de um desenvolvimento autônomo compartilhado com os instrumentos e remédios jurídicos utilizados por países em desenvolvimento.

${ }_{18}$ TAYLOR, Charles. Multiculturalismo. Lisboa: Piaget, 1998, p. 19-20.

${ }^{19}$ Com base na noção de mundo islâmico, alguns exegetas islâmicos elaboraram os conceitos de Dar al Islam e Dar al Harb. O primeiro seria o espaço correspondente aos territórios onde os muçulmanos gozam de plena liberdade para a prática da religião, ou, mais especificamente, os países de maioria islâmica, ao passo que o último conceito quer representar uma alusão aos locais em que os muçulmanos são hostilizados. In: ISBELLE, Sami Armed. Opus citatum, p. 41.

${ }^{20}$ Conforme a seguinte definição: an area in which many races, ideas, etc., are mixed. Collins English Dictionary. 5 ed. Nova Iorque: HarperCollins Publishers, 2000. 
Para tanto, o estudo dividir-se-á em três capítulos, versando, nesta ordem, a respeito: da perspectiva multicultural em que o Islam deve ser abordado; da conceituação de igualdade no sistema sócio-cultural islâmico; e da análise crítica do princípio da igualdade no Islam.

O primeiro capítulo versará acerca da necessidade de se empregar uma perspectiva multicultural ao se perscrutar qualquer fenômeno que implique um dado nível de alteridade, ou seja, que não seja imanente às nossas vivências particulares. Ademais, adentrará à noção de isonomia no Islam, juntamente à idéia de que há a construção de uma ou várias identidades islâmicas, analisando, inclusive, como se dá a sucessão das práticas rituais nas comunidades islâmicas. Por último, verificar-se-á a influência da Lei Islâmica no cotidiano dos muçulmanos.

O segundo capítulo da monografia analisará o valor do princípio da igualdade no Islam, bem como discutirá o seu desenvolvimento histórico. A título de ilustração, haverá breve lição acerca da possibilidade, por meio dos critérios estabelecidos pela Lei Islâmica, de se proceder esforço por raciocínio independente e analítico visando depreender os consequentes lógico-racionais do conceito de igualdade como ele é tido no mundo muçulmano. Ainda, dado se tratarem de temáticas que têm merecido relevo no debate acerca da existência ou não de atenção à igualdade por parte das sociedades islâmicas, ver-se-á quais são as bases para o tratamento dispensado aos não-muçulmanos e as questões atinentes às diferenças de gênero.

No último capítulo empreender-se-á uma análise crítica da utilização prática do princípio da igualdade no Islam, com a tentativa de transposição de alguns argumentos de autores ocidentais acerca da temática, dentre os quais destacamos Cornelius Castoriadis e Max Weber, permitindo-se efetuar a crítica da crítica. Após isto, estabelecer-se-á o marco histórico da tolerância ao outro no Islam e, por fim, o legado comum com o senso ocidental de igualdade.

À guisa da conclusão pretende-se apresentar considerações acerca do Trabalho, respondendo às seguintes hipóteses de pesquisa: "Pode se falar em igualdade em sede de um Direito de base religiosa?"; "Há especificidade no modo como 
os muçulmanos tratam o princípio?"; e "Quais são as bases da abordagem dada ao tema pelo Direito Islâmico?

\section{O Islam sob um enfoque multicultural}

\subsection{Multiculturalismo e Islam}

Ao se considerar o discurso a respeito do multiculturalismo na perspectiva semiótica $^{21}$, partindo da idéia fundamental de que a cultura é um sistema de sinais composto de vários elementos, dentre eles as normas, depreende-se um axioma: a descrição de outra cultura envolve um desafio já que se é obrigado a articular pensamentos lógicos, signos e normas da cultura em que se está inserido como metalinguagem para descrever e compreender a outra cultura ${ }^{22}$.

Ademais, uma aproximação intercultural só pode ocorrer com o emprego inicial e fundamental de "nós" e "eles", "próximo" e "distante”. Nesse processo de divisão de mundos, especificamente no caso do Islam, é possível delimitar fronteiras. Essa delimitação, contudo, não se refere a um espaço determinado, mas a um conjunto de hábitos e práticas que definem o indivíduo como muçulmano. Ainda assim, conquanto se tenha uma definição abstrata do que venha a ser Dar al Islam e Dar al Harb, a realidade é que a cultura islâmica se estende por todo o mundo, pois um fiel, onde quer que seja, estará sempre apto a seguir os mandamentos da doutrina religiosa do Islam.

21 "A Semiótica Jurídica, enquanto ramo das reflexões zetético-jurídicas, surgiu como desdobramento das investigações ligadas à teoria da argumentação, dos estudos de discurso e linguagem, de lógica do discurso jurídico, redundando em um conhecimento específico que se dedica a pensar a dispersão dos signos como fontes de sentido jurídico e a discutir os diversos universos de significação do Direito. As diversas tendências Teóricas contemporâneas debatem acerca de qual a real finalidade do estudo semiótico-jurídico, dividindo-se a partir de suas concepções metodológicas diversas, o que não afasta sua importância como um saber de grande importância para a análise do discurso jurídico”. BITTAR, Eduardo C. B. Verbete: Semiótica jurídica. BARRETTO, Vicente de Paulo. Dicionário de Filosofia do Direito. Rio de Janeiro: Editora Renovar; São Leopoldo, RS: Unisinos, p. 757-760.

22 TERRIN, Aldo Natale. Antropologia e horizontes do sagrado: cultura e religiões. São Paulo: Paulus, 2004, p. 84. 
Como cada tradição constrói seus próprios pontos de vista quanto a seus conceitos idiossincráticos e, visto que não haverá nenhuma correção a ser feita em seu esquema conceitual a partir de um ambiente externo, parece que cada tradição tende a desenvolver seu esquema de maneira que impedirá a transposição de uma tradição para outra. A incompatibilidade lógica exige, em certo grau, que cada tradição identifique os pontos em relação aos quais mantém a sua tese. ${ }^{23}$

Em grande parte, o discurso acerca de culturas pode ser entendido como um reflexo do discurso relativo às religiões. Quando se refere a estas, em seu aspecto institucional, estar-se-á a movimentar num contexto análogo e próprio da cultura $^{24}$. Quando se faz um discurso a respeito da tolerância religiosa, pode-se partir das instâncias culturais relacionadas com as religiões, mas também se pode partir diretamente do senso identitário das próprias religiões, procurando discernir suas dinâmicas internas ${ }^{25}$.

Nessa estrutura dedutiva, as crenças a respeito do que venha a ser Deus ou Allah têm um papel crucial. E quem irá regular isto será a religião.

Os termos Islam e muçulmano derivam de uma mesma raiz: salama. As idéias denotadas por tal raiz lembram sentimentos como paz, saúde, benevolência. O significante Islam - اسلا م traduz o sentido de atingir a paz por meio da "[...] resignação a Deus, conformação a Deus ou submissão a Deus”26.

Cada religião deve ter uma identidade própria e preservá-la, dando a seus fiéis a orientação específica que a caracteriza; não há como se ter um pertencimento múltiplo, uma coabitação comum.

\footnotetext{
${ }^{23}$ MACINTYRE, Alasdair. Justiça de quem? Qual racionalidade?. Trad. Marcele Pimenta Marques. São Paulo: Loyola, 1991, p. 374.

${ }^{24}$ TERRIN, Aldo Natale. Opus citatum, p. 86.

${ }^{25}$ Ibidem, p. 338.

${ }^{26}$ ATTIE FILHO, M. Falsafa: A filosofia entre os árabes - uma herança esquecida. São Paulo: Palas Athena, 2002, p. 38.
} 
As religiões são consideradas sob o aspecto dinâmico e histórico: dessa perspectiva, são figuras em movimento. São surgidas em certo clima histórico, têm uma identidade adquirida com o tempo. A religião tem a sua visão, a sua concepção particular de mundo e, nesse contexto, deve poder convidar os fiéis a escolher. Ela precisa, por natureza, fazer referência a si mesma e enfrentar os problemas e as dificuldades que surgem da interpretação do real e do mundo com base em seu próprio aparato simbólico ${ }^{27}$.

Feitas essas considerações, volta-se à perspectiva multiculturalista para afirmar que o discurso do reconhecimento tem dois níveis: um, mínimo, em que a formação da identidade e do ser são entendidos como resultado de um diálogo; e outro, público, em que a política do reconhecimento igualitário passou a desempenhar um papel cada vez maior. Isto trouxe a mudança de parâmetro da honra para a dignidade, surgindo uma política de tratamento universalista, reconhecendo aquilo que é peculiar a cada um, concedendo-se direitos e impondo-se deveres na medida de suas desproporções ${ }^{28}$.

O que faz com que o raciocínio acerca de justiça e igualdade se valide é que seja compartilhado pela maioria dos membros da comunidade.

Na teorização de justiça como eqüidade, a análise da justiça entre os povos é preterida. No entanto, isto não quer representar que não se possa rever aquilo que se classifica como sociedade plural a partir das exigências impostas pela justiça entre povos. ${ }^{29}$

É importante destacar a noção de igualdade, a qual é mais adequada aos indivíduos que são vistos como livres e iguais e como membros normais e cooperativos da sociedade. Essa idéia implica reciprocidade e respeito às diferenças.

\footnotetext{
${ }^{27}$ Ibidem, p. 86.

${ }^{28}$ TAYLOR, Charles. Opus citatum, p. 57-59.

${ }^{29}$ RAWLS, John. Justiça como eqüidade: uma reformulação. Trad. Claudia Berliner. São Paulo: Martins Fontes, 2003, p.19.
} 
A política de igualdade redefine a não discriminação como um mister que acarreta distinções baseadas no tratamento diferencial. Essa política se baseia num potencial universal, aquele de formar e definir a própria identidade de cada pessoa, como indivíduo e como uma cultura ${ }^{30}$.

A igualdade em seu sentido mais completo e próprio governa as relações entre os indivíduos livres e iguais. O escopo dela é a própria individualidade, sendo que o indivíduo possui identidade e capacidades humanas fundamentais anteriores à sua participação numa ordem social determinada ${ }^{31}$.

Há uma concepção de deveres recíprocos e hierarquicamente ordenados, em que cada um deve e recebe aquilo a que faz jus em termos de expectativas. Família e cidade são exemplos desses sistemas de reciprocidade e viver segundo suas regras significa agir de modo a não romper os sistemas de que cada um é parte. $^{32}$

O respeito às diferenças é um princípio de justiça distributiva que está adstrito tanto à idéia de justiça como à da igualdade eqüitativa de oportunidades. A igualdade é considerada como o que é normalmente necessário para maximizar o bem-estar social. Isto demonstra a vantagem do respeito à igualdade com atenção às diferenças.

Em um mundo em construção que se quer democrático e multiculturalista (não somente multicultural no sentido descritivo, mas no normativo), a abertura para o outro passa, simbolicamente, pelo reconhecimento deste em sua história. Essas aberturas, que criam os espaços de identidade e senso de pertencimento, são elas mesmas igualmente criadas ativamente pelos outros numa fundação nova para a construção de uma "casa comum"33.

\footnotetext{
${ }^{30}$ TAYLOR, Charles. Opus citatum, p. 62.

${ }^{31}$ MACINTYRE, Alasdair. Opus citatum, p.136.

${ }^{32}$ Ibidem, p. 164.

${ }^{33}$ VAKIL, Abdoolkarim. Opus citatum, p. 312.
} 
Este é o marco do multiculturalismo, que traz à tona uma outra política de reconhecimento, onde a diferença e a especificidade assumem um espaço de afirmação, indo além do reconhecimento da igual dignidade ${ }^{34}$.

Se o Islam se encaixa num movimento monoteísta mais amplo, ele também tem, naturalmente, as suas peculiaridades que abrangem todas as esferas da vida. É uma religião, ao mesmo tempo em que é uma comunidade e um modo de viver.

Na visão de um muçulmano a alma é criada por Allah, tendo que obedecer à Sua Lei. E a Justiça não passa de um dos nomes atribuídos a Allah pela doutrina teológica islâmica. O seu padrão seria fornecido ao muçulmano médio por uma forma ideal que o inconsciente tende a apreender. Nessa perspectiva, a idéia de Justiça estaria adstrita à noção do divino. Daí a explicação do porquê, nas sociedades islâmicas, o poder secular tende a se submeter às disposições da Lei revelada, pois as escrituras seriam uma confirmação dos conceitos da moralidade.

A noção islâmica de igualdade é o resultado de uma convenção a que os vários grupos sociais se submetem. Os mais vulneráveis a serem frustrados por outros na consecução dos seus fins ficariam em posição de exigir mais e dar menos. A igualdade será uma disposição para dar a cada pessoa aquilo que merece, de acordo com aquilo que seja a noção islâmica de justiça.

\subsection{0 senso de isonomia no Islam}

O Islam tenta remover imposições das barreiras e das classes entre os membros de sua sociedade a fim de permiti-los apreciar e praticar seus direitos. Nenhuma discriminação de qualquer tipo é permitida no Islam. A linhagem, a classe social, a cor, a origem ou a língua não devem dar aos indivíduos nenhuma classe

\footnotetext{
${ }^{34}$ DA SILVA FILHO, José Carlos Moreira. Multiculturalismo e Movimentos Sociais: o privado preocupado com o público. Disponível em < http://calvados.c3sl.ufpr.br/ojs2/ index.php/direito/article/viewFile/7021/4997>. Acesso: 6 out 2008, p. 7.
} 
ou status especial na sociedade islâmica ${ }^{35}$. Diz-se isso com base nas palavras apontadas como sendo de Mohammad ${ }^{36}$.

Oh humanos! Vosso senhor é um. Vosso Criador é um. Não há nenhuma superioridade para um árabe sobre um nãoÁrabe. Não há nenhuma superioridade para um não-Árabe sobre um árabe. Não há nenhuma superioridade para uma pessoa branca ${ }^{37}$ sobre uma pessoa negra. Do mesmo modo, não há nenhuma superioridade de uma pessoa negra sobre uma pessoa branca à exceção do nível da devoção ${ }^{38}$.

A respeito da questão acima abordada, o pensador árabe Ali Abderraziq conclui:

\begin{abstract}
O Islam é uma religião que não esteve satisfeita com ensinar os ideais de fraternidade e igualdade aos seus adeptos, com inculcar neles a doutrina para a qual homens são iguais como os dentes de um pente, que seus escravos são ao mesmo tempo seus irmãos na religião, que os crentes são aliados uns com os outros, não. O Islam não se apegou a uma educação teórica e isolada de sua doutrina, pelo contrário, o Islam treinou seus crentes a fazer uso dos seus princípios na sua vida cotidiana, educou e exercitou-os a observá-los estritamente em sua atividade. Propôs direitos baseados em fraternidade e igualdade, provou-os com circunstâncias reais e demonstrou as conseqüências de sua validade. Os crentes adquiriram uma vivaz percepção de fraternidade e viveram intensamente o sentimento de igualdade ${ }^{39}$.
\end{abstract}

${ }^{35}$ AL-SHEHA, Abdulrahman A. Misconceptions on Human Rights in Islam. Riyadh: Escritório para propagação do Islam, 2001, p. 23.

${ }^{36}$ Neste trabalho, por se tratar de uma publicação acadêmica, suprimir-se-á o uso da abreviatura "s.a.w.s." - referente à expressão salalahu aleihi wa salam, que em tradução livre do idioma árabe quer dizer "que a paz e a benção (de Allah) sejam sobre ele" e que é comumente encontrada em textos islâmicos.

${ }^{37}$ Em língua árabe: literalmente, pessoa branca de pele rosada (i.e.: branco tingido de vermelho; pessoa caucasiana de pele bronzeada).

${ }^{38}$ Tradução livre do Hadice narrado sob o n 22.978 In: IBN HANBAL, Ahmed ibn Mohammad (Imam). Al-Musnad. Bagdá: [--], 855.

39 ABDERRAZIQ, 1925 Apud ÚRSULA ETTNUELLER, Eliane. Islam and Democracy. Disponível em: <http://www.ub.es/astrolabio/articulos3/ ARTICULOEliane.pdf> Acesso: 29 ago. 2008, p.22. 
O Islam leciona que todos os homens são iguais, contudo, não são necessariamente idênticos. Assim, é natural que governassem suas atividades em harmonia com essas dissimilitudes.

A percepção da não identidade pode parecer contraditória com a afirmação da igualdade como elemento básico do dogma islâmico. No entanto, essa confusão acontece apenas devido ao uso indistinto do termo Islam para descrever uma realidade sócio-histórica e um sistema de crenças metafísicas. O Islam como dogma religioso inspira claramente uma ética igualitária: homens são iguais perante Allah. Não obstante isto, essas almas iguais são nascidas como seres humanos socialmente desiguais, com circunstâncias culturais e históricas muito diferentes.

O princípio da igualdade autoriza a tratar indivíduos desigualmente apenas quando haja motivo para tal.

A partir dessa noção, pode-se recorrer a Aristóteles que dizia que a Lei deveria trazer um enunciado genérico a respeito de "Quem são os iguais e quem são os desiguais", ou seja, acerca de qual o fator legitimamente manipulável que permite distinguir pessoas e situações em grupos apartados para fins de tratamentos jurídicos diversos ${ }^{40}$.

Torna-se impossível falar da existência de uma isonomia absoluta no ordenamento jurídico islâmico, como de resto em todos os direitos de bases religiosas. Na lógica da religião, isto não significa que se esteja ferindo o princípio da igualdade, pois o atributo de crente pode ser atingido por qualquer um disposto a se converter ao Islam. Quanto à diferença no tratamento dado a homens, mulheres, jovens e idosos, a justificativa se encontra nas próprias características dos seres, cabendo tratar os desiguais de forma diferente, de modo a lhes garantir igualdade.

A Lei revelada, ao discriminar, deve se basear em pontos de diferença a que atribua destaque de modo a estabelecer critérios de discriminação justos.

\footnotetext{
${ }^{40}$ BANDEIRA DE MELLO, Celso Antonio. O Conteúdo Jurídico do Princípio da Igualdade. São Paulo: Malheiros Editores, 2002, p. 11.
} 
Qualquer elemento presente nas coisas, pessoas ou situações, poderá ser escolhido pelo Ordenamento como fator discriminatório. Não se deve buscar algum desacato ao princípio da igualdade no traço de diferenciação escolhido ${ }^{41}$.

Para Celso Antonio Bandeira de Mello, as discriminações são recebidas como adequadas à cláusula igualitária sempre que exista um liame de correlação lógica entre a peculiaridade diferencial que reside no objeto e a desigualdade de tratamento em função dela conferida ${ }^{42}$.

A isonomia preceitua que sejam tratadas igualmente situações iguais e desigualmente as desiguais. Donde não há como desequiparar pessoas e situações quando neles não se encontrem fatores desiguais.

Há ofensa à igualdade quando o fator de diferenciação usado para classificar os atingidos pelo cânone legal não detém relação de pertinência com a inclusão ou exclusão no benefício concedido ou com a inserção ou levantamento do gravame imposto ${ }^{43}$.

Para o Islam, a identificação com o Alcorão deve apagar qualquer diferença de raça, cor ou status social entre os homens. Há um hadice - الحديث (afirmações

${ }^{41}$ Ibidem, p. 17.

42 Ibidem, p. 17.

${ }^{43}$ Ibidem, p. 38.

${ }^{43}$ Verifica-se, por tradução livre, que "A importante questão da origem e da legitimidade dos hadice é antiga entre os muçulmanos [...] Uns e outros estão de acordo em que há muitas tradições espúrias". In: BURTON, John. An introduction to the hadith. Edinburgh: Edinburgh University Press, 1994.

Há 4 (quatro) conjuntos de livros principais com as compilações desses ditos e tradições, que são universalmente aceitos nos meios ortodoxos, quais sejam: o Kitab al-Muwatta' de Malik bin Anas, o Musnad, de Ahmad Muhammad bin Hanbal, o Kitab Jami al-Sahih de Sahih Al-Buhari e o Al-Musnadu Al-Sahihu bi Naklil Adli de Sahih Muslim. In: MARTOS QUESADA, Juan. O Direito Islâmico Medieval. In: PEREIRA, Rosalie Helena de Souza (org.). Opus citatum., p. 226.

A Mustalaha al-Hadice ou Ciência do Hadice estabelece alguns critérios para o estabelecimento do grau de confiabilidade de um determinado alegadamente profético, quais sejam: 
devocionais como tradição normativa ${ }^{44}$ de Mohammad que diz claramente que "Os homens são tão iguais entre si como as hastes de um tear; não haverá distinção entre o branco e o negro, entre o árabe e o não-árabe se não se quer incorrer na cólera de Allah".

A comunidade islâmica segue este preceito com razoável grau de rigor e fidelidade. A cerimônia de peregrinação a Meca, por exemplo, é um grande espetáculo multirracial. Ali se misturam todas etnias, cores e nacionalidades todos os anos.

Essa talvez seja uma das explicações históricas para a rápida expansão do Islam. Ao mesmo tempo que admite e tolera a diferença racial e cultural, o mundo islâmico tende a absorver tendências e costumes das novas culturas em que se instala.

É interessante notar que, de modo geral, o Islam não faz distinção formal entre indivíduos com base na fé que professam, diferentemente de outras religiões como o Hinduísmo ${ }^{45}$ (que pelo sistema de castas classifica os indivíduos, uns como superiores aos demais), o Judaísmo ${ }^{46}$ (cujos praticantes se consideram o povo eleito por Deus - sic) ou o Cristianismo, especificamente o católico ${ }^{47}$ (para o qual apenas os cristãos batizados seriam dignos de serem chamados de "filhos de Deus" - sic).

Continuidade da cadeia de transmissores (ittisal assanad);

A integridade moral dos transmissores ('adalah);

A higidez psíquica e a qualidade da memória (thabt) dos transmissores;

A conformidade do Hadice;

Ausência de imperfeição ('illah) no Hadice.

${ }^{45}$ OLIVELLE, J. Patrick. The Law Code of Manu: a critical edition and translation of the Mānava-Dharmaśāstra. Nova Iorque: Oxford University Press, 2005.

${ }^{46}$ Levítico XX:26, in: SEFARDI EN JERUSALÉM, Centro Educativo et OHEL YAACOV, Templo Israelita Brasileiro. Torá - A Lei de Moisés - תרת. Trad. Rabino Meir Matzliah Melamed. São Paulo: Sêfer, 2001, p. 352-353.

${ }^{47}$ Evangelho segundo João I:12-13, In: - . Eyatteaion. Trad. Padre José Raimundo Vidigal (Congregação do Santíssimo Redentor). Aparecida: Santuário, 1983, p. 269-270. Disciplinado no ponto XI de: CONCÍlIUM VATICANUM II. Lumen Gentium: “Constitutio Dogmatica de Ecclesia”. Cidade do Vaticano: Libreria Editrice Vaticana, 1977. Com explanações em: ROSSATTI MACHADO, Jurandir. Batismo: busca e aspectos essenciais. Rio de Janeiro: Comissão Nacional dos Diáconos, 2008. 
O relacionamento do Estado Islâmico com os sujeitos que habitam o seu território será, em grande parte, igual quer se trate de muçulmanos ou não. As únicas diferenças, serão a possibilidade de casamentos inter-religiosos e o acesso a determinados cargos públicos.

\subsection{A construção comunal da identidade Islâmica}

O igualitarismo e a relativa tolerância dos muçulmanos também explicam, em parte, a atração que o Islam exerce sobre minorias étnicas e raciais oprimidas em seus próprios países (por exemplo, os negros nos Estados Unidos da América, que tiveram como alguns de seus importantes líderes pessoas islamizadas, como Malcom X, Mohammed Ali, Louis Farrakan ${ }^{48}$.

As minorias islamizadas passam a se sentir parte de um todo maior - o mundo islâmico - e isso contribui para aumentar a tensão com a sociedade onde estão inseridas e da qual são marginalizadas. ${ }^{49}$

Por um lado, o Islam aparece como um rótulo indicativo, uma entidade aparentemente identificável, simples, monolítica e não diferenciada, apreensível em sua totalidade, não obstante sua óbvia contradição com uma realidade plural, dinâmica, política, social, cultural e ideologicamente diferenciada de bilhões de muçulmanos. De outra parte, o Islam funciona como matriz essencialista e determinante, explanatória de tudo e de todo o fenômeno que, quando se relacionar aos muçulmanos ou às comunidades islâmicas, passa necessariamente a ser islâmico. Falar da comunidade islâmica implica, sempre e desde logo, pensar em termos simultaneamente global e local. Quer em termos de sua formulação jurídica tradicional, ou, enquanto ideal, no imaginário popular contemporâneo, a comunidade islâmica se refere, dentro do seu limite, a umma - أمة, a comunidade global e a solidariedade de todos os muçulmanos.

\footnotetext{
${ }^{48}$ ARBEX JR, José. Islã um enigma de nossa época. São Paulo: Moderna, 1996, p. 32.

${ }^{49}$ Idem, p. 32.
} 
O sentido forte do traço de unidade e solidariedade entre todos os muçulmanos está presente em alguns hadice que se referem aos muçulmanos como membros do mesmo corpo, ou blocos de uma mesma construção, de modo que aquilo que afetar algum deles por todos será sentido. ${ }^{50}$

Daí, a importância de que a igualdade compreenda a noção de que o indivíduo não é apenas formado pelas experiências e insumos personalíssimos, mas também pelas vivências coletivas do grupo em que está inserido.

Como marcos regulatórios, tanto a Torah como o Evangelho, assim como o Alcorão, cada um em maior ou menor medida, aportaram inovações em matéria normativa, em especial no que concerne aos direitos e deveres de cada homem como tal. ${ }^{51}$

Deve-se cultivar uma relação entre os indivíduos em razão da qual todos eles venham a ser portadores dos mesmos direitos fundamentais, os quais provêm, no Islam, de uma Lei revelada e que definem para aquele sistema o que seja dignidade da pessoa humana.

Assim, o Direito Islâmico é que irá regular, nas comunidades religiosas dos muçulmanos, como se devam portar os indivíduos.

Ao contrário do que se pressupõe no Ocidente, todos os indivíduos são iguais perante o código de Lei Islâmica, respeitadas as suas diferenças. As penalidades, os julgamentos e as sentenças são aplicáveis a todas as classes de pessoas sem nenhuma distinção.

A cláusula igualitária, como se irá reconhecer, sofreu importante modificação no Islam. Ela deixou de presumir a igualdade entre os indivíduos e passou a se projetar como conseqüência de um ambiente social de construção de condições para que esta igualdade possa ser efetivamente afirmada ${ }^{52}$.

\footnotetext{
${ }^{50}$ VAKIL, Abdoolkarim. Opus citatum, p. 285.

${ }^{51}$ NOUFOURI, Sumer. La Dignidad de la Persona Humana em el Islam. Disponível em: <http://www.revistapersona.com.ar/sumer.htm>. Acesso: 6 set. 2008, p. 1.

${ }^{52}$ DA SILVA FILHO, José Carlos Moreira. Opus citatum, p. 5.
} 
Na visão islâmica, a origem dos seres humanos é uma só. Teriam sido agregados em povos e tribos para se conhecerem e serem reconhecidos uns pelos outros. Essa divisão não ocorreu, de acordo com os textos religiosos, para jactarem-se de suas descendências. Estariam, deste modo, desincentivadas as práticas discriminatórias $^{53}$.

A dinâmica da interação social da comunidade islâmica tem duas perspectivas. A primeira, tendo por objeto a experiência religiosa, com expressão no quotidiano, centrou-se nas dinâmicas associativistas que se prendem diretamente à prática da religião. É uma perspectiva que se escreve a partir do nível mais baixo, e pode reconhecer a religiosidade enquanto fator de determinação de uma identidade na vida em sociedade, que, partindo da dimensão inter subjetiva da experiência religiosa e da multidimensionalidade do religioso, não negligência a experiência individual, nem a abstrai da sua dimensão social e política no mundo em que se insere. A outra, é a história institucional e política. Seu objeto são as organizações formais e sua negociação do reconhecimento oficial, a legitimação dos porta-vozes da comunidade, do reconhecimento jurídico de suas estruturas, da defesa dos interesses dos membros e de sua imagem na companhia.

Deste ponto de vista, pode-se inclusive afirmar que fora do Dar al Islam a comunidade islâmica é o interlocutor dos muçulmanos, residentes em países que não tem maioria islâmica, perante o Estado e a sociedade civil ${ }^{54}$.

O conceito de sociedade islâmica dado pela Assembléia Mundial da Juventude Islâmica é uma congregação muçulmana unida por um determinado sistema extraído da crença do Islamismo e de seus ensinamentos e que é aprovada pela congregação em geral $^{55}$.

Destes fatores surge, conseqüentemente, uma dinâmica associativa que visa assegurar às condições para a realização dos princípios elementares da vida islâmi-

${ }^{53}$ ZAIDAN, Abdul Karim. O Indivíduo e o Estado no Islam. São Paulo: CDIAL, 1990, p. 80.

${ }^{54}$ VAKIL, Abdoolkarim. Opus citatum, p. 296-297.

${ }^{55}$ MAHÁIRI, Ahmed Saleh. Programa de pregação às minorias muçulmanas. Brasília: Embaixada Real da Arábia Saudita no Brasil, 1985, p. 51. 
ca. Como a condição fundamental preliminar está, evidentemente, a liberdade de consciência e a liberdade para praticar a religião ${ }^{56}$.

Assim, os muçulmanos tendem a ter um maior nível de coesão social do que outros grupos religiosos. A identidade do fiel só é assim entendida se ele estiver enquadrado em algum agrupamento de religiosos. O contrário é uma excentricidade.

Nesse sentido e devido à necessidade de se estar associado a alguma Escola Islâmica ${ }^{57}$, advém o conceito de Taqlid - تَقْليد, querendo representar o seguir uma Escola determinada sem estar ciente disto, por imitação, sendo esta situação admitida quanto à prática ritual, mas não quanto ao dogma monoteísta. Contudo, é de conhecimento geral e admitido nas comunidades islâmicas ortodoxas que o exegeta Ibn Tamyia teria afirmado, certa vez, que "Taqlid representa seguir sem prova e os muçulmanos apenas seguem algo de base comprovada”.

\subsection{0 cotidiano na comunidade Islâmica de fiéis}

O dia muçulmano é regrado pelo intervalo das cinco orações diárias, que nos países de maioria islâmica é anunciado pelo adhan - أَذَان, com chamamento às orações, similarmente ao badalar dos sinos das igrejas anunciando a oração das comunidades cristãs-católicas na Europa pré-industrial. Contudo, em situação de minoria, pela ausência da sua expressão pública e dificuldades de horário, implica outras formas de conscientização da diferença. $\mathrm{O}$ ritmo da vida evolui semanalmente em torno de sexta-feira, quando o muçulmano tem que se deslocar até a mesquita, e anualmente ao redor do jejum obrigatório do mês sagrado de Ramadan, e dos grandes festivais comunitários e de família, o Id-ul-Fitre - عيد الفطر e Id-ul-Adha - الأضحى عيد, que comemoram o fim do Ramadan e o sacrifício exigido de Abraão. Os segundos elementos que sob a condição da minoria fazem sobressair a consciência da diferença, são a modalidade de alimentação que restringe o consumo à carne halal - حلال e proíbe as bebidas alcoólicas. Nos termos do ciclo de vida,

\footnotetext{
${ }^{56}$ VAKIL, Abdoolkarim. Opus citatum, p. 302.

${ }^{57}$ v.g.: Madhabs.
} 
são a união, a criação e a instrução do filho, e a morte que constituem afirmação da diferença religiosa na vida em comunidade. Para alguns, finalmente, a peregrinação de Meca e a prática da caridade ${ }^{58}$.

Em assembléia (jama' - جماعت, sinônimo de umma - أمة), a comunidade expõe sua visibilidade local, o que é sentido e compartilhado pelos muçulmanos como uma realidade concreta. Ao orar na congregação, o crente manifesta, para além da obediência e submissão a Deus - ao demonstrar pela sua atitude a sua identidade de muçulmano - o que ordinariamente certifica nas cinco orações diárias, mais especificamente a comunhão, a fraternidade e a igualdade dos crentes, simbolizadas, na realização da oração própria, pelo movimento uniforme, ritmado e pelos corpos dispostos em conjuntos de linhas retas guiadas no sentido de Meca, ombros ladeados, pés unidos e por fim a prostração ${ }^{59}$.

Mas é durante o Hajj - حج, a peregrinação ritual ao santuário de Meca que é a realização do quinto pilar de fé do Islam que todos os muçulmanos, desde que dispondo dos meios e da saúde necessários, devem procurar realizar pelo menos uma vez na vida - que a umma mais aproximadamente proclame seu senso comunitário no microcosmo. Uma vez ao ano, entre o oitavo e décimo-terceiro dias do mês islâmico de Dhu’ l-hijja - ذو الحجة, milhões de muçulmanos, provenientes da quase totalidade de países do mundo, convergem no ponto de origem do sistema simbólico do ethos islâmico e se equiparam todos pelo uso de peças iguais brancas do algodão, no sinal da renúncia das distinções mundanas, prática, em consonância com todas as gerações de muçulmanos desde a comunidade primitiva dos companheiros de Mohammad. Por outro lado, trata-se da realização de uma reunião anual dos muçulmanos de todos as regiões do mundo, a funcionar como uma espécie de conjunto dos povos, fornecendo uma ocasião única até a revolução digital ${ }^{60}$.

Não é verdade, como tanto se afirma hoje, que o fenômeno de minorias islâmicas em torno do mundo constitui uma realidade absolutamente nova e sem

\footnotetext{
${ }^{58}$ VAKIL, Abdoolkarim. Opus citatum, p. 302.

${ }^{59}$ Ibidem, p. 286.

${ }^{60}$ Ibidem, p. 286.
} 
precedentes. As comunidades islâmicas na China, na Índia e na África contradizem-no. Mas é fato que a expansão atual do Islam e das minorias islâmicas no mundo, a globalização, as tecnologias novas de comunicação e transportes e os mecanismos e acordos internacionais de cooperação e de direitos humanos, criaram a necessidade de reconsiderar estas categorias (v.g.: Islam; minorias), e com elas, os dhimmis - ذمي, ou as minorias não islâmicas sob a autoridade dos muçulmanos ${ }^{61}$.

Isso faz recordar que o Islam é também freqüentemente associado a conflitos no inconsciente coletivo do Ocidente. Para um cidadão branco e de classe média dos Estados Unidos da América, por exemplo, Islam significa não apenas sinônimo de uma religião "estranha" à sua realidade, originária de um povo distante e "fanático". É também, muitas vezes, a personificação de conflitos com negros, hispânicos oprimidos em sua própria cidade ou Estado. O mesmo conflito se reproduz na França em relação aos imigrantes do Magrébe (Marrocos, Tunísia, Argélia e Líbia), que formam uma minoria significativa em algumas regiões de Paris, Marselha e Lyon. Marginalizados, vítimas de preconceitos, eles têm nas mesquitas o único espaço público para discutir os seus problemas ${ }^{62}$.

Observa-se, ultimamente, um crescimento assustador de incidentes violentos anti-ocidentais dentro do mundo muçulmano. No entanto, é de se dizer que não há dentro da religião islâmica mais fatores que predisponham à violência do que em outras culturas ou crenças. Os fiéis que adotam a Char'ia como base da ordem social almejam uma segurança física e psicológica: eles não são mais "sanguinários" do que os demais seres humanos ${ }^{63}$.

Os fundamentalistas (terminologia formulada nos meios neo-pentecostais) podem ser definidos, antropologicamente, como aqueles muçulmanos que se consideram como sendo os verdadeiros crentes, moralmente impelidos a convocar os demais à causa divina com os meios que sejam necessários, pois nada poderia se opor aos desígnios de Allah, na visão deles. Eles tiram suas conclusões de fontes

\footnotetext{
${ }^{61}$ Ibidem, p. 288.

${ }^{62}$ ARBEX JR, José. Opus citatum, p.32.

${ }^{63}$ DEMANT, Peter. O mundo muçulmano. São Paulo: Contexto, 2004, p. 344.
} 
islâmicas comuns a todos os fiéis, apenas que dando uma interpretação restritiva a elas $^{64}$.

O que ocorre é que esses indivíduos não estão errados quando buscam uma coerência com os fundamentos da fé que seguem, mas sim quando dão interpretações personalíssimas a alguns desses conceitos, já consagrados no seio da umma como tendo um significado diverso. Por isso, para a maioria dos muçulmanos, o fundamentalismo, como entendido hoje, representa a desnaturação de sua religião.

Após conceituar um modelo ideal, os literalistas tentam reduzir o papel do mundo islâmico a uma construção deles próprios. O Islam é visualizado como tendo um e mesmo impacto sobre o indivíduo, onde quer que se encontre como sociedade ${ }^{65}$.

\subsection{A Influência da Char'ia no cotidiano}

A maioria dos Estados de maioria islâmica emprega um código parlamentar para estabelecer leis específicas e todos utilizam, em maior ou menor grau, um Sistema de Lei religiosa conhecida como Char'ia, de aplicação semelhante à lei consuetudinária ocidental.

Na inteligência de Juan Martos Quesada, o Direito é comumente definido como sendo o conjunto de normas que regulam a vida comunitária de uma sociedade, de um Estado, tendo estrutura e sistemas de nexos inerentes à sua lógica interna correspondentes ao grau de complexidade a que chega a sociedade em que está inserido. Esse princípio também é válido para o Direito muçulmano ${ }^{66}$.

Em primeiro lugar, é necessário atentar ao elemento religioso latente em todos os aspectos da sociedade islâmica e, portanto, ao caráter nitidamente religioso

\footnotetext{
${ }^{64}$ Ibidem, p. 343.

${ }^{65}$ ÚRSULA ETTNUELLER, Eliane. Islam and Democracy. Disponível em: <http://www. ub.es/astrolabio/articulos3/ARTICULOEliane.pdf> Acesso: 29 ago. 2008, p. 17.

${ }^{66}$ MARTOS QUESADA, Juan. Opus citatum, p. 213.
} 
do Direito Islâmico. A relação divina é o princípio supremo adotado pela doutrina islâmica. Portanto, nenhuma instituição (nem o Direito, nem a Política, nem os institutos mais básicos da vida em sociedade) são alheios à religião ${ }^{67}$.

É sabido que a Char'ia (Lei Islâmica) conta com quatro fontes, na seguinte ordem de precedência hierárquica: o Alcorão (Quran - قرأن - Livro Sagrado do Islam ); a Sunna - لسنة ou tradição; Idjmầ - آدِ جماً ou consenso dos exegetas; e Qiyas - قاً س ou analogia. Os dois primeiros são intangíveis, ao passo que os dois últimos variam de acordo com os ritos ou escolas de interpretação dogmática. Há quatro ritos ortodoxos (Hanifi - حنفي, Maliki - مالكي, Chafi - شافعي) e Hanbali - حنبلى) e um heterodoxo (Ja'fari / X'ia - الجعفري).

As fontes no Direito Islâmico se distinguem das que existem nos Ordenamentos Jurídicos ocidentais, dado não se referirem às normas, mas aos princípios gerais pelos quais se pautam os diplomas legais (qānun - قانو ), atos jurídicos e julgamentos nas sociedades islâmicas. Subsidiariamente às fontes mencionadas, há os decretos religiosos (fatwas - فتو).

A Char'ia concretiza-se por meio do fiqh - فقه (subsunção do qānun à lide), que representa a prática do Direito concreto, semelhantemente aos institutos jurídicos baseados nos sistema jurídicos de Common Law nos países ocidentais.

$\mathrm{Na}$ análise interpretativa dessa Lei, deve-se atentar para o fato de que "no Direito Islâmico, deve-se, para apreciar um ato, investigar a intenção que o movimenta" ${ }^{69}$. E a clara motivação da Char'ia é tratar os indivíduos em pé de um tratamento igualitário, como se observará adiante.

A essência do Islam - conjunto de idéias e conhecimentos - tornou obrigatório que os que desejavam aplicar os mandamentos revelados buscassem desen-

\footnotetext{
${ }^{67}$ Ibidem, p. 214.

${ }^{68}$ GILISSEN, John. Introdução histórica ao Direito. Lisboa: Fund. Calouste Gulbenkian, 1995, p. 120.

${ }^{69}$ Tratado de direito sobre as similitudes e semelhanças In: NUJAYM, Ibn. Al-Bahr Ar-Raaiq. Cairo: [--], 1592.
} 
volver a intelectualidade acerca daquilo que formava o conjunto de suas crenças fundamentais e refletissem a respeito. A tentativa de obter conhecimento religioso, 'ilm - علم iniciou nos primórdios do Islam e fez com que se desenvolvesse, aos poucos, um grupo de estudiosos ('alim, de plural ulemá) muçulmanos.

Paulatinamente, foi ocorrendo uma cristalização de diferentes atitudes em relação aos problemas ligados ao modo de interpretar ${ }^{70}$ as leis islâmicas. Já da passagem ao $2^{\circ}$ (segundo) século posteriores ao advento de Mohammad surgiram os primeiros grupos de escolas de pensamento.

Até o fim do $3^{\circ}$ (terceiro) século islâmico surgiu e se desenvolveu uma escola de pensadores chamados de Mu'tazilis - المعتزلة (ou "os apartados"), que acreditavam que se podia chegar à verdade lançando mão somente da análise racional daquilo que está posto no Alcorão e, assim, alcançar respostas a diversos questionamentos.

Havia, contudo, uma forma mais cautelosa de encarar os problemas que a hermenêutica insistia em lançar sobre o modo de interpretar as revelações. Correspondia a uma forma cautelosa e mais cética quanto à viabilidade de se chegar à verdade por meio da utilização de argumentos exclusivamente racionais. Este segundo grupo parecia considerar mais importante garantir a unidade da comunidade islâmica de fiéis do que chegar a um acordo acerca das questões da doutrina religiosa. A palavra do Alcorão deveria ser interpretada ao lume da prática habitual do profeta Mohammad e seus companheiros e seguidores, ou seja, por meio da Sunna.

${ }^{70}$ Os métodos desenvolvidos pelos exegetas para eliminar antinomias das fontes em Direito Islâmico são, nesta ordem: harmonizar as contrariedades, utilizando-se a técnica de otimização de princípios; em se tratando de normas, dar preferência a uma sobre a outra (priorizando-se a especial em detrimento da geral ou a hierarquicamente superior sobre a inferior); em caso de impossibilidade de utilizar o método anterior, considerar que o cânone revelado posteriormente prevalece sobre o anterior.

In: AL-SHANQEETI, Dr. Muhammad Mukhtar. Scholars Methodology for removing contradition in evidence. Islamic Fiqh Council Journal, Meca: Muslim World League, ano 2003 , n. 16, p. 26-27. 
Em verdade, na inteligência de Ali Kamel todo esse debate acerca de uma suposto antagonismo entre o literalismo e a hermenêutica pode levar a um discurso um tanto quanto viciado em relação ao que venha a ser o fundamentalismo religioso. Essa discussão estaria, segundo o jornalista, dominado por uma certa confusão. Modernamente, passou-se a rotular de fundamentalista qualquer pessoa mais obediente aos preceitos de sua crença ou confissão, ou seja, todo aquele que eventualmente acredite ter encontrado "A Verdade" e que deseje seguir naquilo que considere ser o caminho dela. Estes, no entanto, seriam - tão somente - os profundamente religiosos. Opção deles. Direito deles. Isso poderá fazer deles fanáticos, mas não necessariamente fundamentalistas. Pelo menos não na acepção que hoje se dá ao termo. ${ }^{71}$

Para além daí, contudo, não se pode perder de vista que o Judaísmo, o Cristianismo e o Islam têm uma miríade de movimentos e seitas, todas gravitando ao redor do núcleo principal. Se o judaísmo tem ortodoxos, reformistas e liberais, o Cristianismo tem diversas denominações entre evangélicos e católicos romanos ou ortodoxos e, também, o Islam compreende uma infinidade de seitas entre os ramos sunitas e xiitas. ${ }^{72}$

Apesar de se verificar uma tendência maior a que os sunitas se apegassem a esta última corrente de pensamento, ao contrário dos xiitas (que por reconhecerem um número maior de versículos de significado oculto/não-aparente no Alcorão admitiam com maior facilidade o seu submetimento aos rigores de uma análise racional para que se chegasse ao seu significado último), não é correto dizer que a maioria da ortodoxia islâmica rechaçou a utilização da razão, como se pode depreender do Discurso Decisivo ${ }^{73}$ do filósofo sunita Averróis, Abū '1Walīd Muhammad ibn Ahmad ibn Rushd - الوليد محمد بن احمد ابن رشد أبو.

\footnotetext{
${ }^{71}$ KAMEL, Ali. Sobre o Islã: afinidade entre muçulmanos, judeus e cristãos e as origens do terrorismo. Rio de Janeiro: Nova Fronteira, 2007, p. 171-172.

${ }^{72}$ Ibidem, p. 171.

${ }^{73}$ AVERRÓIS. Discurso Decisivo. Trad. Aida Rameza Hanania. São Paulo: Editora Martins Fontes, 1994.
} 
Neste livro ${ }^{74}$, Averróis tentou responder, por volta do ano 1180 - sob a perspectiva do exame jurídico - se o estudo da filosofia e das ciências da lógica é permitido pela Lei Islâmica. Para comprovar que a Revelação prescreve a reflexão sobre os seres existentes fazendo uso da razão, invoca-se uma série de versículos do Alcorão, como por exemplo: "Acaso não examinaram o reino dos céus e da terra e todas as coisas que Allah criou?75" [VII, 185] e, também, "Refleti, ó vós que sois dotados de clarividência ${ }^{76 "}$ [LIX, 2].

Partindo de semelhantes concepções, bem anteriores à acima exposta, as linhas de pensamento e estudo sobre as quais o Islam se articulou desenvolveram-se.

Essas Escolas de raciocínio foram numerosas, mas claramente relacionadas entre si. O primeiro ponto de estrangulamento entre aquilo que pregaram foi a questão da autoridade.

O espaço de aplicação precípuo da Char'ia seria o Estado Islâmico, no qual o califa é o soberano. Tem-se a noção de que ele administra, mas que quem governa de fato é Allah, ou de modo mais simples, o califa só faria aquilo que Allah permitisse.

Ali Abderraziq expõe as duas principais teorias de origem do califado. A primeira tenta demonstrar que o poder deriva diretamente de Allah, o califa é portanto um representante de Deus na terra. A segunda teoria segue a hipótese de uma delegação de responsabilidades a partir do povo, da umma para o califa. A necessidade de justificativa para as origens do poder não têm sido uma exclusividade islâmica, mas têm seus paralelos no pensamento ocidental em duas linhas de argumentação nas reflexões de Hobbes e Locke. O califado é a instituição islâmica por excelência ${ }^{77}$.

\footnotetext{
${ }^{74}$ Ibidem.

${ }^{75}$ NASR, Helmi. Tradução do sentido do Nobre Alcorão para a língua portuguesa. Medina: Complexo do Rei Fahd, 2005, p. 271.

${ }^{76}$ Ibidem, p. 921.

77 ABDERRAZIQ, 1925 Apud ÚRSULA ETTNUELLER, Eliane. Opus citatum, p. 20.
} 
Haveria, ainda, o argumento de que a necessidade do califado decorria de ser absolutamente vital para garantir um correto estilo de vida islâmico ${ }^{78}$.

Há que se salientar a autonomia da esfera jurídica com relação ao poder político no Islam, desde a época do medievo.

Segundo a construção doutrinal de qualquer uma das quatro escolas ortodoxas [...], o califa não deve ter nenhuma ingerência no âmbito do Direito, limitando o seu poder de criação e arbítrio à esfera mais puramente administrativa e política, no dizer de Shacht ${ }^{79}$.

O fato é que, ainda que o califa fosse a figura central do governo islâmico, via de regra, delegava ao qâdi - قاضي a função de ser seu longa manus para a aplicação e distribuição da justiça. Os juízes religiosos gozavam de plenitude de jurisdição e tinham, ainda, alguns outros múnus, como a gestão dos bens dos órfãos e das fundações, a partilha de sucessões, etc.

O qâdi Al-Nubāhī destacou algumas funções desta espécie de servidor público, dentre as quais os deveres de: julgar entre os litigantes e aplicar a justiça aos infratores da Lei; distribuir justiça aos oprimidos; velar pelos interesses dos alienados mentais/deficientes psíquicos em qualquer grau; administrar o espólio no caso das sucessões; ocupar-se de matrimônios (contratos civis) e da administração dos bens dos órfãos; administrar bens procedentes de Fundações Pias (Waqfs Islâmicos - وقف); aplicar o Direito Penal; julgar com igual justiça a ricos e pobres, homens e mulheres; escolher testemunhas fiéis e honradas, etc ${ }^{80}$.A decisão final do qâdi é, em tese, inapelável. Cabendo, no caso do Islam sunita, unicamente a possibilidade de apelo à clemência do califa. Não obstante isto, na Arábia Saudita, no Paquistão e em outros países onde o Islam é a religião oficial, tem-se verificado a formação de Cortes de Apelação (formadas por Conselhos de Muftis).

\footnotetext{
${ }^{78}$ Ibidem, p. 22-23.

${ }^{79}$ SHACHT, 1964 Apud. MARTOS QUESADA, Juan. Opus citatum.

${ }^{80}$ AL-NUBĀHĪ, Abu Hassan. Al-Marqaba al-’Ulyā. Cairo: Dar al-Katib al Misrī, 1948, p.42.
} 
Isto se deve a um aspecto bastante relevante do Direito Islâmico, qual seja o seu caráter consultivo ${ }^{81}$. Em todos os tratados, há um capítulo especificamente voltado a tratar essa temática. Assim, se o qâdi é o indivíduo dotado da capacidade de julgar, deve cercar-se de um conselho composto por juristas e muftis.

Os qâdi têm, no entanto, progressivamente perdido parcelas de sua esfera de poder competente para juízes laicos, notadamente desde o fim do califado turco-otomano em $1924^{82}$.

Não obstante o unitarismo religioso e jurídico, os Estados Islâmicos passam atualmente por mudanças distintas em seus sistemas jurídicos. Quer parecer que, apesar de uma crescente ocidentalização jurídica do lócus onde se aplica, o Direito Islâmico não desaparecerá ${ }^{83}$ enquanto perdurar o Islamismo como religião de cerca de 1/5 (um quinto) da humanidade ${ }^{84}$. Mais do que europeizar suas instituições, os muçulmanos islamizam as instituições européias ${ }^{85}$

81 i.e.: Conselho Consultivo ou Majilis Al-Choura - مجلس الشورى: é resultado de um princípio utilizado pelo Profeta Mohammad e por seus companheiros à época da fixação do Estado Islâmico em Medina, na atual Arábia Saudita.

${ }^{82}$ GILISSEN, John. Opus citatum, p. 123.

${ }^{83}$ Exemplo disto se deu na República da Turquia - após a queda do Califado, sob o governo de Mustafá Kamal "Atatürk” - que objetivou aplicar o Código Civil suíço de 1926 teve problemas de ordem prática, qual fosse o fato de que todos os casais seguiam mantendo os seus matrimônios segundo o Direito Islâmico e não de acordo com o Código Civil. Desde aquela época até hoje, foram realizadas dezenas de reformas nas leis turcas, dado que havia a necessidade de estatuir formas de reconhecer os filhos havidos na constância das mencionadas uniões matrimoniais. Antes, as crianças eram legítimas pelos critérios islâmicos, mas não pela legislação civilística.

${ }^{84}$ Com um percentual de $19,2 \%$ da população mundial, os muçulmanos formam o maior grupo religioso do mundo, como se verifica em: FOMMENTI, Monsignor Vittorio. Annuario Pontifício 2008. Cidade do Vaticano: Libreria Editrice Vaticana, 2008.

${ }^{85}$ GILISSEN, John. Opus citatum, p. 123. 


\section{Igualdade e Islamismo}

\subsection{O valor do conceito de igualdade no Islam}

Há motivos para a peculiaridade do modo como o Direito Islâmico trata a personalidade. Quando um sistema jurídico é mais um produto religioso, de consciência, e menos um produto de disposições sociais - como no caso islâmico - o campo de incidência desse Direito tende a embasar seus princípios no conceito de personalidade. As ilações fundadas no regulamento jurídico muçulmano serão igualmente válidas para um indivíduo na Indonésia e um outro no Marrocos, desde que sigam a mesma escola de raciocínio jurídico ${ }^{86}$.

O valor da igualdade não deve, contudo, confundir-se com a identidade ou o estereótipo. Há, quanto a eles, diferenças de habilitações, bens e pretensões, dentre outros. Mas nenhuma destas diferenças pode estabelecer, por si só, um estatuto de superioridade de certo povo ou raça sobre outros.

A despeito disso, o respeito à igualdade no Islam atingiu um requinte tal que de uma carta do segundo califa Omar Ibn Al Khatab (governante do Império Islâmico de 634 a 644 da era cristã) se extrai: "Controle o povo pela sua constância, através do seu contato direto, e dispensando equidades de modo a que nenhum nobre o insulte nem nenhum fraco se decepcione com a sua justiça" ${ }^{37}$.

Comentando a questão, o iraniano Hamid Enayat ${ }^{88}$ afirmou que a igualdade reconhecida pelo Islam, ao contrário do que ocorreu entre os gregos (que dão base à concepção ocidental do que seja isonomia) não está subordinada a quaisquer pré-condicionamentos. A igualdade para os gregos tinha apenas o significado que lhe desse a Lei; abstrato, portanto. A isonomia ali garantia igualdade não porque todos os homens fossem nascidos iguais, mas, pelo contrário, porque eram naturalmente desiguais e necessitavam de um instituto artificial, a Pólis, que pelas suas normas os igualaria, virtualmente. Para o Islam, os seres humanos são nascidos em

\footnotetext{
${ }^{86}$ SIEGMAN, H. The State of individual in sunni Islam. The Muslim World. Hartford: Blackwell Publishing, n. 54, p. 188-195, ano 1964.

${ }^{87}$ ZAIDAN, Abdul Karim. Opus citatum, p. 84.

${ }^{88}$ ENAYAT, 1982 Apud HOOGAR INSTITUTE. Opus citatum.
} 
igualdade e se tornam desiguais por razões sociais ou políticas. A igualdade para o Islam não é um atributo da Polis ou de uma região ou povo, é uma virtude inata a todos os indivíduos.

É de se ressaltar que o valor da igualdade não é uma mera questão de direitos ou de convenção entre particulares. Trata-se, antes, de um artigo de fé que o muçulmano tem de levar a sério e aderir sinceramente, como exigência da religião. Os alicerces deste valor estão profundamente enraizados na estrutura do Islam.

Percebe-se, por exemplo que que crime que atenta contra a igualdade é considerado como um dos ilícitos de maior gravidade pelas normas da Char'ia. Os crimes são classificados em três categorias, pela doutrina islâmica, quais sejam: Houdoud - حدود; Diyat wa Qisas - قعاص دية و; e, Ta'zir - تعزير, sendo que uma maneira aproximada de defini-los seria agrupando-os, respectivamente, como crimes contra o sistema religioso, contra a sociedade muçulmana e contra o indivíduo tutelado pelo Estado Islâmico ${ }^{89}$. Os tipos descritos sob o primeiro gênero têm punição fixada pela Lei religiosa, os da categoria subseqüente podem ser punidos com a retaliação ou com a condenação a uma compensação à família da vítima, ao passo que os últimos serão sancionados conforme a discricionariedade do qâdi, levando-se em consideração a sua gravidade.

Introduziu-se tal conceituação para afirmar que um ato qualquer de desrespeito à igualdade é criminalizado na Lei Islâmica, podendo ser considerado como atentando, concomitantemente, contra o sistema religioso, a sociedade, bem como contra o indivíduo que sofre a discriminação. Contudo, é de se dizer que, em linhas gerais, costuma-se enquadrá-lo como sendo Ta'zir, pois a despeito de estar previsto como ilícito na Lei Islâmica, não se estipulou a gravidade da penalidade a que o agente que o pratique estaria submetido, cabendo ao Juízo estabelecido determiná-la de modo proporcional à ofensa cometida.

A principal característica distintiva desse sistema de doutrinas religiosas é a igualdade entre seus fiéis, talvez uma herança dos beduínos. Essa idéia se deve em

\footnotetext{
${ }^{89}$ SHMALLEGER, Frank. Criminal Justice Today. Nova Jersey: Prentice Hall, 1993, p. 603.
} 
muito ao fato de não haver a noção de que pagãos teriam a marca de um pecado original, nem a idéia de salvação pelo sacrifício de um redentor que estaria acima dos demais fiéis, nem sacerdotes com o exclusivo poder de ministrar sacramentos imprescindíveis para o resgate da alma dos crentes $^{90}$.

\subsection{Desenvolvimento histórico do princípio da igualdade no Islam}

A doutrina religiosa do Islam dá grande ênfase aos princípios da fraternidade humana e da igualdade. Seu senso igualitário é, muitas vezes, apontado como um dos elementos que contribuíram para o rápido avanço desta religião. Eventos históricos e parábolas expressando esse ideário entre os primeiros muçulmanos, particularmente na figura profética de Mohammad, são abundantes e largamente referendados pelos exegetas islâmicos ${ }^{91}$.

Por sinal, o mundo em que o islamismo se desenvolveu, ao tempo do século VII, era permeado por iniqüidades. A leste, havia uma elaborada estrutura social e um rígido sistema de classes na Pérsia pré-islâmica e, para além dali, havia o regime de castas nos domínios do hinduísmo. Ao oeste, havia os sistemas de aristocracia baseados na hereditariedade, os quais o cristianismo recepcionou das civilizações greco-romanas. Ademais, existia um grande número de praticantes do judaísmo, os quais se consideravam como o "povo escolhido" de Deus e, portanto, superiores aos gentios (do hebraico: goyim - גוים), não-judeus ${ }^{92}$.

O Islam, em princípio, não admitiu a existência de castas ou de uma aristocracia. Quanto às primeiras, a rejeição islâmica se deu tanto no plano teórico como prático. Já a vedação à existência de uma aristocracia foi sempre uma matéria muito mais controvertida. Como em qualquer sociedade humana, os indivíduos mais bem sucedidos conseguiram viabilizar maneiras de transmitir poder e riquezas à

\footnotetext{
${ }_{90}$ DEMANT, Peter. Opus citatum, p. 36.

${ }^{91}$ JAHANBAKHSH, Forough. Islam, Democracy and Religious Modernism in Iran. Boston: Brill, 2001, p. 32.

${ }^{92}$ LEWIS, Bernard. The political language of Islam. Chicago: The University of Chicago Press, 1988, p. 64.
} 
sua descendência. Decorreu daí uma inevitável tendência à formação de grupos de privilegiados. Sob o Estado Islâmico, esse fenômeno ocorreu a despeito dos ditames da doutrina religiosa dominante e não como parte de sua ideologia.

Contudo, as condições prevalentes de insegurança enfraqueceram a posição de privilégio de alguns desses grupos. As aristocracias muçulmanas eram precárias e, em geral, de curta duração. Muitas foram depostas por sucessivas ondas de conquistas, cada qual criando uma nova e efêmera classe dominante.

Entretanto, é de se dizer que, na Lei Islâmica, nunca houve nada que pudesse servir de paralelo à divisão romana da sociedade em patrícios e plebeus ou que se pudesse comparar aos suseranos e vassalos da Idade Média européia.

O termo islâmico para o indivíduo "livre", até o século XVIII, tinha um significado primariamente normativo e, ocasionalmente social, representando aquele que, de acordo com a lei, não tinha relação de servidão com nenhum senhor. Nem o termo "livre", nem "servo" eram utilizados como tópicos políticos e o uso ocidental dos termos "liberdade" e "servidão" - como metáforas para direitos dos cidadãos e para tirania - era desconhecido do discurso político clássico islâmico.

As tentativas de conciliar uma análise de nível metafísico com um aspecto sociológico da questão, como fruto da discussão dos exegetas islâmicos, usualmente acabavam sendo incompletas. Isso se deveu à idéia que advogavam: a de que um conceito qualquer seria tão sustentável quanto fosse teologicamente justificável. Em relação ao que foi mencionado, será útil que o leitor discrimine o que foi é o “islamismo real", moderno ou tradicionalista daquilo que é o "Islam autêntico", entendido como sistema doutrinário que transcende ícones cronologicamente pontuais de seu próprio desenvolvimento histórico, dada a sua dimensão como um complexo fenômeno sócio-religioso ${ }^{93}$.

Ocorre que o Islam, como sistema, não se opunha doutrinariamente à servidão, sempre que se mantivesse claro que servo e senhor podiam ser socialmente

${ }^{93}$ GARCÍA CRUZ, Jose Fernando. Opus citatum, p. 18. 
de classes distintas, mas eram iguais perante Allah. A doutrina ocupava-se, isto sim, de regular a sua prática, estabelecendo limites ao seu exercício, já que o Islam pretende ser um sistema de vida completo e não apenas uma religião, regulando todos os aspectos da vida em sociedade.

Nesse sistema sócio-religioso não era permitido ter alguém como servo/escravo por motivo de sua origem, raça ou religião, mas sim como resultado de atos criminais, guerras de conquista ou no caso de submissão voluntária à servidão, em geral, para se livrar do estado de miserabilidade.

O Alcorão, contudo, conclama os muçulmanos a não apenas ajudarem os servos/escravos na obtenção da alforria (de modo que gradualmente, a servidão/ escravidão se extinguiu nos domínios islâmicos), mas a se empenharem no resgate dos cativos de guerra, conforme se observa nas suas seguintes passagens ${ }^{94}$ : II: 177 e IV: 36. Ademais, o Islam estipulou condições mínimas de respeito à Dignidade da Pessoa Humana, a despeito de se tratar de indivíduo livre ou não, no que se diferenciou frontalmente dos sistemas que tiveram gênese contemporânea a ele.

A maioria dos países islâmicos seguiu a tendência internacional e proibiu completamente a servidão no século XIX. No ano de 1926, a Conferência Islâmica Mundial adotou resoluções condenando severamente a servidão e a escravidão. ${ }^{95}$

\subsection{Estabelecimento do ljtihad}

Alguns filósofos muçulmanos aproveitam o dito corânico de que "Esse é o livro. Nele, não há dúvida alguma. É orientação para os piedosos” [II, 2] ${ }^{96}$, para

\footnotetext{
${ }^{94}$ NASR, Helmi. Opus citatum, p.46.

95 "Os seres humanos são nascidos iguais e não têm o direito de escravizar, humilhar, oprimir ou explorar quaisquer indivíduos e não deve haver jugo algum, salvo aquele devido a Allah, o Altíssimo", visível no art. 11 da Declaração encontrada no seguinte documento: CONFERÊNCIA ISLÂMICA, Ministros de Relações Exteriores dos Países Membros da $19^{a}$. The Declaration on Human Rights in Islam. Cairo: ORGANIZAÇÃO DA CONFERÊNCIA ISLÂMICA MUNDIAL, 1990.

${ }^{96}$ NASR, Helmi. Opus citatum, p.4.
} 
afirmar que o homem, por ser dotado de razão deve ponderar acerca dos bens da vida e neles constatar sinais da criação.

Averróis escreveu obras que tratam do estatuto legal do estudo da filosofia dentro da doutrina islâmica e chegou à conclusão de que a filosofia, enquanto consistindo pura e simplesmente no exame racional dos entes, culminaria numa espécie de prova teológica da existência de um criador. Chegar-se-ia à conclusão de que a utilização de estudos filosóficos é, não apenas permissível, mas incentivada pela religião ${ }^{97}$.

Este comentador afirma textualmente que:

Já que a revelação é a verdade, e que ela convida a praticar o exame racional que assegura o conhecimento da verdade, então nós, muçulmanos, sabemos de ciência certa que o exame [dos entes] pela demonstração não conduzirá a nenhuma contradição com os ensinamentos trazidos pelo Texto revelado: pois a verdade não pode ser contrária à verdade, mas concorda com ela e testemunha a seu favor ${ }^{98}$.

Isto vem no sentido de confirmar o Hadice imputado como sendo de Mohammad, o qual afirma que "A primeira coisa criada por Allah foi o intelecto", bem como a afirmação do Califa Ali ibn Abu Thalib que dita: "Allah não deu a Seus seguidores algo mais estimável do que a inteligência"99.

O esforço, por raciocínio independente e pensamento analítico, literalmente significa Ijtihad - اجتهاد, em árabe, que é a utilização da razão na elaboração e na aplicação da Char'ia, estando apto a conceber, desta forma, um veredicto jurídico a respeito de qualquer questão para a qual não haja regra específica ${ }^{100}$.

\footnotetext{
${ }^{97}$ AVERRÓIS. Opus citatum., p. XVI.

${ }^{98}$ Ibidem, XXII.

${ }^{99}$ CLEARY, Thomas F. O essencial do Alcorão: o coração do Islã. Trad. Pedro H. Berwick. São Paulo: Jardim dos Livros, 2008, Epígrafe. ${ }^{100}$ ISBELLE, Sami Armed. Opus citatum, p.142.
} 
O Ijtihad, como boa parte das questões básicas no Sistema Jurídico Islâmico tem sido objeto de um autêntico processo histórico de decantação. Em primeiro lugar, há de se destacar a noção de evidência determinante para o estabelecimento de um juízo legal, ou huyyah, sobre a qual se exerce o esforço analítico. Para os autores sunitas, estas evidências se reduzem ao Alcorão e à Sunna, ao passo que para os xiitas o esforço se realiza, também, analisando as evidências provenientes dos ditos dos "Imames Infalíveis"101. Para a ortodoxia islâmica, o Ijthad é centrado na opinião personalíssima do jurisconsulto, a partir da evidência literal, ou, melhor dizendo, por meio da codificação normativa, essencialmente baseada no uso do Qiyas (raciocínio analógico), chegando a um juízo por meio de seu livre entender acerca da matéria ${ }^{102}$.

Em outras palavras, não há, para a corrente majoritária do Islam, uma interpretação dogmática advinda de uma estrutura eclesiástica do tipo Igreja, e as hierarquias decorrentes desta opção, ao contrário do que ocorre no caso do xiismo ${ }^{103}$.

Desse modo, ocorre a emergência de um esforço jurídico secular, também, mas que não se desvencilha dos institutos de ordem teológica. A definição desse esforço está nas palavras de Alasdair Macintyre:

A aplicação de princípios fundamentais a uma situação particular exige um conjunto adicional de capacidades: não só a capacidade de deduzir, dos princípios fundamentais gerais e universais, princípios mais específicos com a aplicação mais imediata a tipos específicos de situação, mas também a capacidade de fazer derivar os juízos práticos particulares sobre o que deve ser feito aqui e agora [...] O nome "conscientia" é aplicado a essas capacidades ${ }^{104}$.

Entretanto, essa tendência racionalizante observada em algumas correntes da religião islâmica não se deu de forma linear, notadamente no Islam sunita. Foi, isto sim, uma tentativa de conferir sistematização lógica a certas práticas voltadas

\footnotetext{
${ }^{101}$ i.E.: modo como os muçulmanos xiitas se referem a alguns dos descendentes do Profeta Mohammad.

${ }^{102}$ GARCÍA CRUZ, Jose Fernando. Opus citatum, p. 21.

${ }^{103}$ Ibidem, p. 21.

${ }^{104}$ MACINTYRE, Alasdair. Opus citatum, 1991, p. 203.
} 
para a relação com o divino. Práticas estas que se confundem com o desenvolvimento do que se poderia chamar de Islam "ortodoxo" ${ }^{105}$.

A interpretação só seria dada por pessoas preparadas para tal finalidade em Madrassas e seminários islâmicos. Esses são os mujtahids, ou uma espécie de doutor em Lei Islâmica. São eles que baixam os decretos islâmicos ou fatwas. E é nestes que se encontrará a regulação para a questão da igualdade no seio do Islam.

A despeito de alguns exegetas islâmicos terem aludido ao fato de que a Revelação possuiria um significado aparente e outro oculto, com relação à questão da igualdade, sempre se considerou que as evidências fossem suficientes para não deixar dúvidas a respeito do status que lhe seria conferido pelo Islam.

É de se apontar que os valores erigidos em bens jurídicos relevantes no Islam, inclusive o conceito de igualdade, nem sempre são validados em uma base racionalista apenas.

O termo usado pela língua árabe para designar igualdade é al-musāwāt المساواة, com raiz triliteral derivada de sawiyah A palavra musāwāt e seus derivados são usados como significantes no estudo das Ciências Jurídicas Islâmicas, numa base de análise ora legalista, ora de plano moral ${ }^{106}$.

Na modernidade, os termos musāwāt, no idioma árabe, musāvāt em turco e barābarī em língua persa, são utilizados para conceituar politicamente o que venha a ser igualdade humana. A primeira vez que se utilizou o termo no mesmo sentido político que lhe é emprestado hoje foi com a tradução dos princípios da Revolução Francesa, em 1798 pelo Secretário-Chefe do Império Otomano. Traduziu-se, em turco, égalité et liberté como musāvāt vê serbestiyet. Também, na tradução para o árabe da proclamação de Napoleão Bonaparte, quando da tomada do Egito por

\footnotetext{
${ }^{105}$ SOARES, Marina Juliana de Oliveira. Traços de racionalismo oriental: os estudos de Weber sobre o Islã. Revista Travessias, Cascavel: Universidade Estadual do Oeste do Paraná, p. 8-9, n. 1, ano 2005.

${ }^{106}$ JAHANBAKHSH, Forough. Opus citatum, p. 32.
} 
suas tropas, consagrou-se a equivalência de significado entre o termo francês égalité e musāwāt ${ }^{107}$.

\subsection{A igualdade na lei Islâmica - Al-musāwāt}

A igualdade perante a Lei é uma forma de manifestação do princípio da igualdade. Ela é um requisito de justiça que não é dispensado pelo Islam. A Lei se aplica a todos sem uma distinção injustificada qualquer. A aplicação desse princípio vem sendo passado através das gerações a partir dos exemplos da tradição profética árabe-semita ${ }^{108}$.

As evidências corânicas da igualdade podem ser classificadas como se atendo a dois temas principais. Um deles é o que se relaciona à fraternidade entre os crentes, sua unidade na fé, enquanto o outro diz respeito à fraternidade humana de forma mais ampla, senão vejamos a passagem aposta no Alcorão, no oitavo versículo de seu capítulo V:

Ó vós que credes! Sede constantes em servir a Allah, sendo testemunhas com equanimidade. E que o ódio para com um povo não vos induza a não serdes justos. Sede justos: isso está mais próximo da piedade. E temei a Allah. Por certo, Allah do que fazeis, é Conhecedor ${ }^{109}$.(Grifo nosso)

E mais adiante, no nonagésimo versículo do capítulo XVI, lê-se:

Por certo, Allah ordena a justiça e a benevolência e a liberalidade para com os parentes e coíbe a obscenidade e o reprovável e a transgressão. Ele vos exorta, para meditardes ${ }^{110}$.(Grifos nossos)

Nesta seara, a Char'ia firma posição em favor da igualdade e justiça. Esses são dois princípios de direitos humanos, os quais são prioritários à estrutura de valores do próprio Islam. Tomava-se, assim, uma rigorosa posição acerca da igual-

\footnotetext{
${ }^{107}$ Ibidem., p. 33.

${ }^{108}$ ZAIDAN, Abdul Karim. Opus citatum, p. 82.

${ }^{109}$ NASR, Helmi. Opus citatum, p. 171.

${ }^{110}$ Ibidem, p.434.
} 
dade num ponto da história em que esta era uma norma que estava longe de ter uma aceitação unânime. Dado o cenário daquelas sociedades há quatorze séculos, a visão islâmica de criar um senso igualitário era uma verdadeira revolução.

A Char'ia também reconhece o direito à igualdade no atendimento das necessidades de bem-estar das pessoas. Desta forma, intitula-se a cada indivíduo uma assistência financeira pelo Tesouro Público, não apenas se tomando por base a sua contribuição. A distribuição dos recursos públicos não pode ter bases em discriminação por raça, gênero ou origem étnica.

O princípio também é observado no campo da tributação. Todos os muçulmanos são sujeitos ao pagamento de taxas legais (Zakat), as quais são um dever imposto pela religião como ato caritativo, ao passo que os não muçulmanos são obrigados ao pagamento de taxas territoriais (Jizia).

Ultimamente, as sociedades islâmicas parecem ter buscado criar um sistema em que a equidade, e não o lucro, governa soberanamente as vidas dos muçulmanos. A economia islâmica tem dois objetivos primários: combater a pobreza e prover uma justa distribuição das riquezas. O Estado Islâmico efetiva isto por meio de uma variedade de mecanismos mandatórios e voluntários. Por exemplo, o zakat (caridade) é uma poderosa ferramenta de redistribuição de renda, transferindo pelo menos $2,5 \%$ de todo lucro anual para os mais pobres da sociedade ${ }^{111}$. A abolição da riba (usura) previne esquemas injustos de empréstimos, os quais penalizariam os mais necessitados. Em adição, o Estado é demandado a prover a cada indivíduo um padrão mínimo de vida ${ }^{112}$.

As obrigações são geralmente reduzidas a fórmulas para definir a justiça: deve ser concedido o que é devido a cada pessoa em relação ao mérito, com casos

\footnotetext{
${ }^{111}$ Explicite-se que este percentual pode variar muito, elevando-se para 5\% em caso de agricultores/pecuaristas que não tenham gastos com insumos, ou com sistemas de irrigação e para $25 \%$ no caso de empreendedores de atividades mineradoras ou petrolíferas.

${ }^{112}$ HAMID, Shadi An Islamic Alternative? Equality, Redistributive Justice, and the Welfare State in the Caliphate of 'Umar. Disponível em: <http://www.renaissance.com.pk/Augvipo2y3.html> Acesso em 20 out. 2008, p.1.
} 
semelhantes sendo analisados em termos iguais e os distintos com o correto grau de proporcionalidade ${ }^{113}$.

As características naturais poderiam ser, para alguns, utilizadas como motivos para atribuir direitos básicos desiguais, definindo posições relevantes. Essas características são imutáveis e as posições que elas especificam devem ser pontos fundantes a partir dos quais a estrutura básica de Sistema Jurídico tem de ser julgada. O limite mais simples que se imporá a tais medidas deverá ser a de que tendam a garantir a igualdade no acesso aos bens sociais.

O bem comum é definido como a distribuição de talentos naturais, ou seja, a diferença entre as pessoas. Essas diferenças consistem na variedade de talentos de determinados tipos. Essa variedade de capacidades torna possíveis inúmeras complementaridades, quando estão devidamente organizadas para que se aproveite a diversidade ${ }^{114}$.

Por outro lado, Ronald Dworkin ${ }^{115}$ lembrava que o ideal abstrato da igualdade não implica necessariamente tratamento idêntico em todas as situações, mas sim o direito de ser tratado como um igual, ou seja, com o mesmo respeito e consideração que todos os demais ${ }^{116}$.

Ademais, todos os cidadãos de um Estado Islâmico são iguais nas cortes de justiça quanto à submissão às leis. Nos procedimentos legais para peticionar a concessão da pretensão alegada, assim como os procedimentos de defesa, no regulamento das provas, na aplicação das sentenças, na execução dos mandados, na necessidade de diligências, em tudo isso, não cabe discriminar entre os litigantes ${ }^{117}$.

\footnotetext{
${ }^{113}$ MACINTYRE, Alasdair. Opus citatum, p.44.

${ }^{114}$ RAWLS, John. Opus citatum, p. 107.

${ }^{115}$ DWORKIN, Ronald. Taking rights seriously. Londres: Duckworth, 1977, p. 227.

${ }^{116} \mathrm{~A}$ esse respeito, vide texto relativo à nota 150 .

DWORKIN, 1977 Apud MOTTA FERRAZ, Octávio Luiz. Justiça Distributiva para formigas e cigarras. Disponível em: < www.cebrap.org.br/imagens/Arquivos/critica01 ferraz.pdf $>$. Aceso em: 22 set. 2009.

${ }^{117}$ ZAIDAN, Abdul Karim. Opus citatum, p. 83-84.
} 
É de se apontar que esta prática se dá desde a época dos ditos califas ortodoxos, (que sucederam a Mohammad no poder), sendo que no Ocidente, até o século XVIII, com o advento das reformas penais, os processos judiciais se pautavam pela incerteza das penas, arbitrariedade da execução e irrecorribilidade das decisões.

\subsection{0 tratamento dispensado aos não-muçulmanos}

Os indivíduos não-muçulmanos no Estado Islâmico são divididos em duas categorias principais: os "Povos do Livro" (Ahl al-Kitab - أهل الكتاب), compreendendo os judeus e os cristãos; e, os ditos "idólatras" (Káfirun - الكافرو ن), os quais não professam fé em nenhuma das Escrituras admitidas pelos muçulmanos como tendo sido divinamente reveladas (v.G.: Torah, Salmos, Evangelho e Alcorão).

A relação entre os muçulmanos e os integrantes dos "Povos do Livro" é regulada por um pacto chamado dhimma. Os beneficiários desta convenção são chamados dhimmis. Os termos do acordo garantem às comunidades dhimmi segurança para seus indivíduos, direitos de propriedade, liberdade religiosa (restringindo-se o uso de símbolos externos) e um determinado grau de autonomia, em troca do reconhecimento da primazia do Islam como sistema religioso. Esse reconhecimento era expresso pelo pagamento da Jizia como tributo e símbolo de submissão ao Estado Islâmico. ${ }^{118}$

Os dhimmis têm liberdade para praticar a sua religião em privado, mas não podem exercer seus cultos em público ou praticar atos de proselitismo.

De acordo com a Char'ia, os dhimmis, como minoria religiosa, têm autonomia para conduzir os assuntos de suas próprias comunidades, conforme suas leis e costumes, ao passo que, com relação ao Direito Público, estão submetidos às regulações estatais.

${ }^{118}$ JAHANBAKHSH, Forough. Opus citatum, p. 34. 
Costumavam ser, ademais, legalmente impedidos de exercer ofícios da Administração Pública os quais requeiram exercer autoridade sobre muçulmanos, contudo essa vedação vem sendo mitigada em função do Hadice, o qual dita que: "Aquele que é incumbido de algum assunto dos muçulmanos e nomeia para executá-lo alguém, apesar de haver outra pessoa mais competente disponível, terá atraiçoado Allah e Seu Profeta" ${ }^{119 ”}$.

Destarte, tem se observado um sem-número de cristãos e judeus exercendo cargos de mando em Estados de orientação islâmica, como foi o caso de vários Vizires do Califado (i.e.: Ministros do Sultão; Conselheiros políticos e/ou religiosos do governante), Ministros e Parlamentares de países islâmicos e até mesmo Presidentes de Repúblicas árabes, apenas para ficar em alguns exemplos ${ }^{120}$.

Os judeus e cristãos aderentes ao pacto de dhimma são considerados cidadãos do Estado Islâmico, ao passo que os indivíduos classificados pela ortodoxia muçulmana como “idólatras” não são entitulados com o benefício dessa cidadania. $\mathrm{O}$ antagonismo entre este último grupo e os muçulmanos só é relativizado pela existência de pactos de salvo-conduto ou proteção, chamados de $A m \bar{a} n^{121}$.

Aos 13 de julho de 1878, o Império Turco-Otomano, (moderna denominação do califado islâmico), acordou com a Rússia e com o Império Austro-Húngaro os termos do Tratado de Berlim ${ }^{122}$, por meio do qual as potências mencionadas se

\footnotetext{
${ }^{119}$ ZAIDAN, Abdul Karim. Opus citatum, p. 75.

${ }^{120}$ Há alguns exemplos bastante recentes e de repercussão mundial: a presença de um judeu, de nome André Azulay, como conselheiro pessoal do Rei do Marrocos, Mohammad VI; a nomeação da Sr. ${ }^{a}$ Houda Nonoo como Embaixadora do Bahrein (um Emirado Árabe de regime confessional Islâmico) perante os Estados Unidos da América, em maio de 2008; A eleição repetida de cristãos católicos para ocuparem a Presidência do Líbano, um país de maioria muçulmana, dando cumprimento a um acordo que vigora naquela República; a presença do cristão caldeu, Tariq Aziz, como alto representante (Ministro das Relações Exteriores) do governo do ex-ditador iraquiano Saddam Hussein no Iraque; a presença, por força legal, de representantes da comunidade judaica no Parlamento da República Islâmica do Irã etc.

${ }^{121}$ JAHANBAKHSH, Forough. Opus citatum, p. 34-35.

${ }^{122}$ MELLO, Celso D. de Albuquerque. Curso de Direito Internacional Público. 14 ed. Rio de Janeiro: Renovar, 2002.
} 
comprometiam a não impor tratamento discriminatório a seus cidadãos em razão de características étnicas, raciais ou de opção religiosa. Em realidade, o referido Tratado ${ }^{123}$ serviu mais para obrigar os Impérios Russo e Austro-Húngaro a conferir aos seus súditos de origem islâmica o mesmo tratamento que o califado dispensava aos judeus e cristãos que habitavam o seu território.

A despeito de atentar, em linhas gerais, ao princípio da igualdade, o Islam estabelece que, naquilo que atine à liberdade religiosa são estatuídas algumas diferenciações na possibilidade de acesso a determinados direitos por parte dos indivíduos em razão do fato de se vincularem ou não à fé islâmica.

Contudo, não se deve utilizar este fato como foco de observação monolítico visando estatuir se há ou não respeito à igualdade no mundo muçulmano, sendo que todas as sociedade estabelecem situações de sua predileção e incentivam tais atitudes por parte dos membros que as compõem.

Com efeito, alguns entes federados dos Estados Unidos da América reputam alguns bens jurídicos de sua predileção como inalienáveis e punem aqueles que atentam contra eles com a pena capital. Isto constitui uma opção de legisladores estadunidenses, sem que contudo as pessoas digam que lá não há respeito à igualdade ou à liberdade porque se optou por restringir tais e quais comportamentos.

Na República Francesa, conforme disposição da Lei 1.905/2004, é negado a uma jovem muçulmana que use um hijab - حجاب o direito à educação no sistema público, ao passo que estudantes cristãos podem andar com crucifixos expostos ou os estudantes de origem judaica podem usar os seus kippa - כיפות sem serem incomodados. Não obstante isto, os acadêmicos ocidentais não se levantam em

\footnotetext{
${ }^{123} \mathrm{O}$ tratado de Berlim, (que contou com a participação dos Impérios Alemão, Austro-Húngaro, Russo, Turco-Otomano, do Reino Unido e da República Francesa), reconheceu a independência dos Principados da Romênia, Sérvia, Montenegro e a autonomia da Bulgária, conquanto esta ficasse sob a tutela formal do califado otomano. A Macedônia foi devolvida ao Estado Islâmico e a província otomana da Bósnia e Herzegovina foi posta sob administração austro-húngara, embora permanecesse oficialmente integrando os territórios sob a jurisdição islâmica.
} 
nenhum momento para dizer que a França está em claro desrespeito ao direito à igualdade de milhões de seus cidadãos ${ }^{124}$.

Ao mesmo tempo, no Brasil, a sociedade parece majoriamente ser favorável a uma noção que enxerga o núcleo familiar, que é digno de proteção, como sendo aquele conformado pela união matrimonial ou não de um homem e uma mulher ( sistema heterossexual monogâmico). Ocorre, que é uma opção do legislador a de privilegiar a união mormente aceita pela sociedade, inclusive, por força de ideário sócio-religioso predominante no país, de cunho cristão. Isto é uma opção sancionada pelo Estado Brasileiro, independentemente de a Constituição Federal assegurar a todos os cidadãos a igualdade perante a Lei, sem distinção de qualquer natureza.

Antes, viu-se uma opção do legislador norte-americano. Todas as sociedades fazem opções fundamentais e é em torno do conjunto de objetivos que decorrem dessas decisões construídas comumente que se constitui cada Estado Nacional. Onde houver um grupo humano organizado qualquer, haverá o Direito e, resta claro, que o último será quase sempre resultado daquela sociedade em que esteja inserido.

O fato de todas as Cortes brasileiras (inclusive os Tribunais Superiores), o Congresso Nacional e Assembléias Legislativas, o Gabinete Pessoal do Presidente da República, as Representações Diplomáticas da República Federativa do Brasil perante outros Estados e a quase totalidade dos órgãos públicos do país contarem com símbolos cristãos nunca faz com que os agnósticos, ateus, budistas, messiânicos, xintoístas, hinduístas, zoroastros, judeus ou muçulmanos, (brasileiros ou aqui residentes), alegassem que não têm respeitado o seu direito de igualdade perante

\footnotetext{
${ }^{124}$ A República Francesa vedou o direito dos estudantes vestidos com indumentária tipicamente islâmica de assistirem aulas em seu sistema de educação pública, desde o ano de 2004 (Lei de inicativa do Presidente da República) e, conquanto - diante da reação negativa de bem mais do que os cerca de $10 \%$ da população, referentes aos muçulmanos franceses - tenha-se retirado a eficácia do mencionado Diploma Legal, ele permanece tecnicamente em vigor.

Vide: GIDDENS, Anthony. Voile islamique: la France sur la mauvaise voie. In: Le Monde. Paris: Groupe Le Monde, ed. 14.01.2004, p.1, ano 2004
} 
a Lei; como de outro modo sempre tem ocorrido no território de todos os Estados latino-amercianos e europeus que dessa forma procedem.

Assim é que, a despeito de vários países ocidentais fazerem claras opções por determinados conjuntos de valores, os quais são solidificados em seus mais diversos corpos normativos, isto nunca fez com que se questionasse o fato de os muçulmanos ali residentes terem ou não respeitado o seu direito à igualdade por parte desses Estados.

Não seria razoável, por semelhante noção, esperar que sociedades que estão sob Estados de cunho confessional islâmico premiassem o fato de cidadãos não-muçulmanos refutarem a fé islâmica. Isto se constitui igualmente no reflexo de uma clara opção feita pela maioria dos integrantes daquelas referidas sociedades, assim como os fatos mencionados acima refletem a opção feita pela maioria dos integrantes das sociedades ocidentais.

Contudo, em geral, dão provas de que o Islam pode se constituir em sociedades com razoáveis graus de tolerância, ao contrário do que muitos afirmam: os $20 \%$ de egípcios coptas (que contam com dezenas de assentos no Parlamento do país com maior população árabe do mundo); os cristãos maronitas da República do Líbano, que contam com vários assentos no Congresso Nacional Libanês e têm assegurado exercício da Presidência da República, (por força de acordos celebrados com outros Estados de maioria muçulmana, notadamente o de Taif, assinado em 1989 na Arábia Saudita), isto ocorrendo a despeito de estarem num país de maioria islâmica; o fato de a instituição do califado ter contado com inúmeros Vizires cristãos; as centenas de milhares de judeus, cristãos e zoroastros de nacionalidade iraniana, os quais contam com representantes próprios no Parlamento daquele país, por exigência do artigo 64 da Constituição da República Islâmica do Irã; o fato de o Papa Bento XVI ter podido realizar uma missa campal, aos 10 de maio de 2009, para um público superior a 30.000 pessoas (segundo a imprensa internacional ${ }^{125}$ ), em plena capital do Reino Hachemita da Jordânia; a presença de

${ }^{125}$ DONADIO, Rachel Pope celebrates Mass in Jordan. Disponível em: <http://www.nytimes.com/2009/05/11/world/middleeast/11pope.html> Acesso em 23 set. 2009. 
um judeu, de nome André Azulay, como conselheiro pessoal do Rei do Marrocos, Mohammad VI; a nomeação da Parlamentar judia Houda Nonoo como Embaixadora do Bahrein (um Emirado Árabe de regime confessional Islâmico) perante os Estados Unidos da América, em maio de 2008; dentre outros inúmeros exemplos.

\subsection{A igualdade de gênero}

Naquilo que tange à igualdade de gênero, pode-se dizer que a religião islâmica considera homens e mulheres iguais quanto à essência da dignidade humana, quanto à recompensa pela conduta pessoal e aos assuntos pertinentes à moral e religião. Há controvérsia, no entanto, quanto a se as mulheres têm respeitado seu direito à igualdade em relação à sua participação na política.

Há igualdade quanto a encargos pessoais e responsabilidades comuns e, também, no pagamento por seus feitos.

Em verdade, a atitude do Alcorão e dos primeiros muçulmanos dão conta de que, como parece óbvio, para o Islam a mulher é tão vital ao desenvolvimento do mundo como o homem e de que ela não é inferior a ele. A despeito de serem consagrados tais direitos há um grande número de muçulmanos que seguem desrespeitando as normas de sua própria religião. Não fosse isso, a questão não teria despertado tanto interesse no mundo ocidental.

A despeito das críticas que se possa tecer sobre a opção legal de se punir severamente o adultério ${ }^{126}$, tanto o praticado pelo homem como o praticado pela mulher, este é um fato que, na prática, tem tendido a gerar comportamento sexual mais responsável e faz com que as mulheres muçulmanas, em geral, estejam mais

\footnotetext{
${ }^{126}$ Trata-se de uma das heranças islâmicas das disposições da Torah judaica, como se vê a seguir: "Se um homem se deitar com a mulher do próximo, certamente serão mortos o adúltero e a adúltera", visto em Levítico XX:10 e, ainda, "Se um homem for encontrado deitado com mulher que tenha marido, morrerão ambos, o homem que se tiver deitado com a mulher, e a mulher. Assim exterminarás o mal de Israel”, visto em Deuteronômio XXII:22.
} 
protegidas de doenças sexualmente transmissíveis, dada a inibição da infidelidade. As taxas de contaminação pelo vírus HIV, por exemplo, é menor do que meio ponto percentual em cerca de $90 \%$ dos países islâmicos, de acordo com dados da Organização das Nações Unidas ${ }^{127}$.

A esse título, o estupro também é situação repudiada pelo Islam e a dura sanção ao estuprador desencoraja os possíveis criminosos, conquanto se reconheça que sob a perspectiva da Criminologia Crítica tal visão possa merecer alguma restrição ${ }^{128}$.

A mulher tem direitos e responsabilidades, na teoria islâmica clássica, assim como os homens, mas estas prestações e ônus a que fazem jus ou se submetem não são necessariamente idênticos aos dos homens. Essa diferença é inteligível, pois os homens e as mulheres são, para a doutrina religiosa em tela, distintos por natureza, mas não em essência.

Um dos pontos que despertam inquietação é a questão da necessidade de cobrir partes do corpo. Apesar de se notar que na maior parte do mundo islâmico os homens também tem o hábito de cobrir quase que o corpo todo com suas vestes (i.E.: jellabiya, keffyeh, taqia, etc) é inegável que tal dever se impõe mais rigidamente, nos diversos extratos sociais, sobre as mulheres.

No entanto, a "obrigatoriedade" em usar o véu (hijab), que representa o ponto nodal da discussão, não é uma prática especificamente islâmica, mas sim

${ }^{127}$ UNAIDS. 2007 AIDS Epidemic Update. Disponível em: <http://www.unaids.org/en/ KnowledgeCentr e/HIVData/EpiUpdate/EpiUpdArchive/2007/default.asp >. Acesso em: 28 jul. 2009.

${ }^{128}$ A esse respeito vide BARATTA, Alessandro. Criminologia Crítica e Crítica do Direito Penal. Trad. Juarez Cirino dos Santos. 2 ed. Rio de Janeiro: Freitas Bastos, 1999.

${ }^{128}$ A Lei rabínica proíbe a recitação de bênçãos e orações na presença de mulheres casadas com a cabeça descoberta, uma vez que o cabelo é considerado nudez, como se vê em: BRAYER, Menachem B. The Jewish Woman in Rabbinic Literature: A psychosocial perspective. Nova Iorque: Ktav Publisher House, 1986, p. 316-317. Se verifica noção semelhante no seio do Cristianismo, conforme se verifica do cânone 1262 do Código 
uma herança cultural antiga, com analogia tanto no Judaísmo como no Cristianismo ${ }^{129}$.

É intrigante notar que o fato de freiras católicas usarem seus hábitos, que incluem véus ou a necessidade de que as mulheres judias casadas tenham suas cabeças cobertas para entrar numa sinagoga ou na área do "muro das lamentações" não gera na opinião pública nenhum impulso tendente a considerar tais questões como sinais inequívocos de opressão de gênero. Contudo, quando se tratam de mulheres muçulmanas, o fato costuma gerar inquietação nas organizações feministas ao redor do mundo.

Deve-se apontar, contudo, que o véu se transformou em motivo de apologia entre alguns muçulmanos que partem para uma interpretação mais literal da lei revelada, caindo nas mãos de uma intolerância patriarcal em alguns locais do mundo islâmico. Para a ala radical dos adeptos do Islam, o véu se tornou um instrumento de controle da mulher, privada de escolha quanto à sua própria indumentária. Mas há que se ter claro o fato de que as situações análogas à descrita constituem exceção e não regra, sendo que, em linhas gerais, o uso do hijab constitui uma reivindicação das muçulmanas, baseada em seu senso identitário.

É de se assinalar que não foi a doutrina islâmica que colocou, em dado momento, a mulher como fonte de todo o mal, produto do diabo ou algo parecido. Tampouco levantou questionamentos sobre se a mulher tinha ou não alma. Nunca na história daquela religião se pôs em dúvida o fato de que a mulher tem grandes predicados morais e espirituais. A isto se deve o fato de que, isoladamente, a dita idéia de "pecado original" não se estende, para o Islam, como uma mácula a toda humanidade e especialmente às mulheres, as quais teriam segundo algumas outras tradições religiosas sido condenadas por Deus a sentir perpetuamente as dores

de Direito Canônico de 1917, plenamente em vigor conforme os arts. 20 e 21 do Código de Direito Canônico atualmente em vigor, o que, de outra forma, ratifica o exposto na I Epístola de Paulo aos Coríntios [XI: 3-7]: “[...] Todo o homem que ora ou profetiza, tendo a cabeça coberta, desonra a sua própria cabeça. Mas toda a mulher que ora ou profetiza com a cabeça descoberta, desonra a sua própria cabeça, porque é como se estivesse rapada. Portanto, se a mulher não se cobre com véu, tosquie-se também. Mas, se para a mulher é coisa indecente tosquiar-se ou rapar-se, que ponha o véu [...]" 
do parto como sinal de castigo, visão veementemente repudiada pelos estudiosos islâmicos.

O Alcorão, texto sagrado dos muçulmanos, dita que "A quem faz o bem, seja homem ou mulher, enquanto crente, concederemos uma vida agradável. E nós recompesá-lo-emos com prêmio melhor do que aquilo que faziam” [XVI, 97]. Essa afirmação é tomada, pelos muçulmanos mais moderados, como demonstração de que não se deve fazer distinção baseada em características de gênero, o que de todo modo, não parece ser a posição adotada na totalidade dos casos.

Mister ressaltar que é consenso entre historiadores que, na tradição islâmica, a mulher tem, desde a época de Mohammad, há exatos 1.400 anos, portanto, direito a voto, à herança ${ }^{130}$ e ao divórcio, o que só foi alcançado pelas mulheres ocidentais no último século.

Infelizmente, a Lei Islâmica tem se caracterizado por uma considerável distância entre teoria e prática. Hoje em dia, a Char'ia aplica-se, em realidade, na medida em que não se choca com a consciência popular. Se esta Lei se opõe a uma norma consuetudinária muito ancada na consciência popular, recorre-se a subterfúgios, a ficções jurídicas (hiyal - هيل)

De forma geral, as mulheres têm os mesmos direitos que os homens, sendo que estes as suplantam em deveres, devendo, inclusive, arcar com o sustento da família, ao passo que as últimas podem despender suas riquezas do modo como mais lhes aprouver. A exceção quanto à igualdade de direitos é o Direito de Família, especificamente quanto à possibilidade de se contrair casamentos múltiplos (até o número máximo de quatro).

\footnotetext{
${ }^{130} \mathrm{De}$ acordo com a Char'ia, a mulher tem direito à metade do quantum recebido pelo homem numa partilha em que, hipoteticamente, ambos concorram na vocação hereditária. Deve-se ter em mente, contudo, que nas relações gerais da vida civil das comunidades islâmicas, o homem é legalmente obrigado a arcar com as despesas de sustento da família, ainda que a esposa exerça atividade remunerada, ao passo que à mulher é facultado despender tudo o quanto ganhe com os gastos de sua predileção pessoal. $\rightarrow$ ISBELLE, Sami Armed. Opus citatum.

${ }^{131}$ NOUFOURI, Sumer. Opus citatum, p.5.
} 
O matrimônio é um contrato de Direito Civil, solene, fundado esencialmente no consentimento mútuo dos esposos. No matrimônio, a mulher guarda seus próprios bens. Tem direito a ser mantida (nafaqa), vestida e alojada sem que tenha que participar dos gastos. Abu Huraira narrou que o Mohammad teria dito: "O Crente mais íntegro é aquele que demonstra melhor caráter e de melhor moralidade. E o melhor dentre vós é aquele que melhor trata a sua mulher, e o que é melhor para com a sua mulher"132.

É de se dizer que, quanto ao casamento, não existe pela Lei Islâmica a possibilidade de haver o que se costuma chamar no Brasil de "casamentos arranjados", ou seja, aqueles que ocorreriam sem o consentimento de um dos nubentes, sendo expresso pela Char'ia que tanto a mulher como o homem devem manifestar a sua aceitação, cabendo a esta, ainda, estipular uma quantia a ser paga pelo noivo diretamente a ela (dote) no ato do casamento.

Uma outra crença de que se difundiu no Ocidente é a de que o Islam incentivaria a mutilação genital feminina, dado que houve notícias relativas a esta prática por muçulmanos africanos. O que ocorre, aí, é que nem todas as práticas de um muçulmano serão necessariamente homologadas pela religião. É este exatamente o caso, sendo mister ressaltar que várias tribos cristãs africanas realizam tal procedimento, o qual é repudiado tanto pelo Islam quanto pelo Cristianismo.

\section{Análise crítica do princípio igualitario no Islam}

\subsection{A transposição de uma crítica}

Em realidade, o debate a respeito da igualdade, bem como aquele acerca da liberdade, está impregnado por algo que se poderia chamar de uma ontologia antropológica, uma metafísica relativa ao ser humano. Para Cornelius Castoriadis, no entanto, assentar a igualdade humana em tais bases seria insustentável, sendo que

${ }^{132}$ Ibidem, p. 3. 
este mesmo autor entende como anacrônica a exigência de se calcar a igualdade ou a liberdade numa suposta vontade divina ${ }^{133}$.

Além disto, esses "fundamentos” filosóficos metafísicos se tornariam, em sua utilização, quase que metafóricos. Bastaria, segundo Castoriadis, algum deslizamento lógico ou a adição de uma nova premissa, anteriormente implícita, para daí se derivar uma apologética da igualdade ou o seu inverso. ${ }^{134}$

Castoriadis segue desfiando a linha de raciocínio acima descrita para tecer algumas críticas ao sistema doutrinário do Cristianismo (especificamente do Catolicismo, quer Romano, quer Ortodoxo), as quais poderiam, em algum sentido, ser transpostas ao Islam. Aduz que, em teologia, a rigor, só se trata de prospectar a existência da igualdade perante Deus, mas não a ocorrência da mesma nas esferas social ou política. ${ }^{135}$

A prática religiosa quase sempre aceitou e justificou as desigualdades terrenas. O igual estatuto dos seres humanos - enquanto "criaturas" - perante Deus, legitimaria uma noção que os fiéis mais devotos poderiam chamar de um destino eterno das almas deste mundo. Não importaria, no balanço que se faz a respeito do valor aferido à existência do indivíduo, o modo como se teve respeitado ou não o acesso à igualdade no correr de seu tempo de vida intramundana, temporal ${ }^{136}$.

Para Cornelius Castoriadis seria estranho observar alguns pensadores tentarem fazer da igualdade transcendente do espírito humano, do modo como professada por alguns sistemas religiosos, o antecedente dos modernos conceitos acerca da igualdade social e política ${ }^{137}$.

\footnotetext{
${ }^{133}$ CASTORIADIS, Cornelius. Encruzilhadas do Labirinto - domínios do homem. Trad. José Oscar de Almeida Marques. Rio de Janeiro: Paz e Terra, 1987, p.314-334.

${ }^{134}$ Ibidem, p.314-334.

${ }^{135}$ Ibidem, p. 334-335.

${ }^{136}$ Ibidem, p.314-334.

${ }^{137}$ Ibidem., p.314-334
} 
Especificamente quanto ao objeto deste trabalho é tecida a seguinte asserção:

Há um paradoxo em afirmar que o ponto de vista do islamismo, por exemplo, vale tanto quanto todo e qualquer outro - quando o ponto de vista do islamismo consiste em afirmar que só o ponto de vista do islamismo vale. $\mathrm{E}$ nós próprios fazemos o mesmo: afirmamos que só o nosso ponto de vista, segundo o qual há equivalência de culturas, vale - negando, com isto, precisamente, o valor do ponto de vista eventualmente "imperialista" desta ou daquela cultura $^{138}$.

Não seria equivocado, para o autor citado, lembrar que o dito "estatuto da igualdade das almas" é excessivamente ambíguo, pois que advogar semelhantes idéias se compatibiliza com a doutrina mais extremada da predestinação, do destino manifesto, que cria classes sociais metafísicas, ou social-transcendentes, no além e para toda a eternidade.

Esta criação e esta fabricação implicam sempre a forma abstrata e parcial da igualdade, pois a instituição opera sempre dentro e através do universal, ou daquilo que denomino o conjuntista-identitário: ela age por meio de classes, propriedades e relações. A sociedade, tão logo se institui, instaura de chofre uma "igualdade" supranatural entre os seres humanos que é algo distinto de sua similaridade biológica, pois a sociedade não pode instituirse a não ser estabelecendo relações de equivalência. Ela deve dizer: os homens, as mulheres, os que têm entre dezoito e vinte e um anos, os que habitam tal aldeia... ela opera, necessariamente, por meio de classes, relações, propriedades. Mas esta "igualdade" segmentária e lógica é compatível com as desigualdades substantivas mais agudas. Ela sempre é equivalência quanto a tal critério ou, como os matemáticos dizem, módulo de alguma coisa. Em uma sociedade arcaica, os membros de uma certa "classe de idade" são "iguais" entre si - enquanto membros dessa classe $^{139}$.

Para além dessas considerações, a idéia de uma igualdade social e política substantiva é um signo construído em comunidade e, mais especificamente, uma

\footnotetext{
${ }^{138}$ Ibidem, p.342.

${ }^{139}$ Ibidem, p.334-335.
} 
idéia que corresponde a um topos, algo que envolve a instituição da sociedade enquanto comunidade politicamente organizada.

Aquilo a que se deve estar atento é que o fato de tratar-se ou não a religião de uma relação privada com o ente divino é um assunto secundário quando aquela adquire relevância social e política por meio de dispositivos legais. A partir deste ponto, a influência da religião pode sujeitar os indivíduos e seu acesso à igualdade de condições, a uma submissão aos decretos revelados.

Em realidade, pode-se afirmar que Max Weber foi o primeiro autor ocidental a enfrentar o Islam enquanto objeto sociológico, embora adstrito aos limites dos conhecimentos que possuía acerca do fenômeno social em escopo.

Weber tentou passar em resenha doutrinas outras que o Cristianismo para demonstrar a incompatibilidade do espírito do capitalismo com as éticas econômicas que decorreram desses contextos por ele estudados. O objetivo era sempre o de captar o sentido que um ator social confere à própria ação, com foco em delinear uma tipologia abstrata apta a fornecer um instrumental interpretativo da realidade social e histórica. ${ }^{140}$

O Islam foi circunscrito por Weber, enquanto objeto sociológico, como um sistema doutrinal regido por uma ética guerreira, de militância engajada com os princípios daquela fé, que aos poucos teria colocado de lado a possibilidade de evolução para modelos do tipo capitalista ${ }^{141}$.

Weber estendeu seus estudos sobre o judaísmo antigo, o cristianismo (protestantismo), o budismo, o hinduísmo, o confucionismo e o taoísmo ${ }^{142}$. Em seus escritos acerca do Islam, observou que: “O Islam do primeiro período é uma re-

\footnotetext{
${ }^{140}$ WEBER, 1992 Apud PACE, Enzo. Sociologia do Islã: fenômenos religiosos e lógicas sociais. Trad. Ephraim Ferreira Alves. Petrópolis: Vozes, 2005, p. 16.

${ }^{141}$ Ibidem, p. 16-17.

${ }^{142}$ SOARES, Marina Juliana de Oliveira. Traços de racionalismo oriental: os estudos de Weber sobre o Islã. Revista Travessias, Cascavel: Universidade Estadual do Oeste do Paraná, n. 1, p. 2, ano 2005
} 
ligião de guerreiros dedicados à conquista do mundo, uma ordem de cavaleiros, disciplinados combatentes em prol da fé, nos moldes do cristianismo da época das Cruzadas"143.

Com a vênia devida à relevância do conjunto da obra de Weber, não se pode concordar com suas posições acerca dos fenômenos sociológicos que se observam no mundo muçulmano, ao se observar que o Islam não se pauta exclusivamente pela figura de Mohammad e, mais ainda: que, com relação a este líder, não se atém unicamente a seu carisma, como quer afirmar o sociólogo, mas também ao seu exemplo de vida, (como por exemplo o fato de que era comerciante e participava de caravanas, o que era comum entre os árabes), sendo descabida a afirmação de que a doutrina islâmica pregue um isolamento absoluto das coisas mundanas.

De tela, observamos que o Alcorão inicia o $256^{\circ}$ versículo do capítulo II

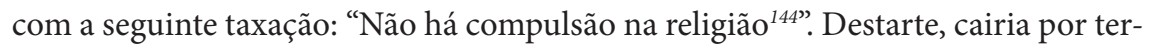
ra a afirmação de muitos de que o Islam seria uma doutrina belicosa que prescreve o avanço desta religião sobre as demais por meio do emprego das armas (v.g.: à ponta de espada).

Talvez, o equívoco de Weber reflita a noção errônea de muitos ocidentais a respeito dos pilares da fé islâmica, chegando-se à incorreção de dizer que Jihad - جهاد (que é um conceito central na religião islâmica) representaria a forma traduzida para o árabe do termo "Guerra Santa". Nada mais equivocado, dado que, em realidade, Jihad quer dizer "esforço na causa de Allah"; algo mais próximo do sentido de "Batalha Espiritual" empregado nos meios cristãos evangélicos neo-pentecostais para representar o embate com os espíritos malignos. A noção de "Guerra Santa", por sua vez, seria traduzida para o árabe como al-Harb al-Muqadassa - الحرب المقدسة que é uma expressão que não é encontrada no texto corânico, sendo um conceito periférico da religião islâmica.

\footnotetext{
${ }^{143}$ WEBER, Max. Ensayos sobre Sociología de la Religión. Trad. Livre. 2 ed. Madri: Taurus, 1992, p. 235.

${ }^{144}$ NASR, Helmi. Opus citatum, p. 71.
} 
Nesse sentido, é essencial, nos dizeres da iraniana Chahla Chafiq, diferenciar-se Islam, enquanto corpo de doutrinas religiosas, do Islamismo, que seria o discurso que surge como reflexo da projeção do primeiro sobre o ambiente político. A autora, marxista, opõe-se diametralmente às tentativas de forjar uma identidade religiosa comum a todos os fiéis, uma das ideias mais defendidas em alguns meios religiosos muçulmanos. Diz ela:

Não existe, de fato, uma comunidade islâmica de fiéis, assim como não existe apenas uma comunidade francesa postada por detrás de qualquer projeto social ou político. Alguém pode ser francês ou iraniano, muçulmano ou judeu, mas pertencerá sempre primeiro a seu(s) grupo(s) social(is): família, trabalho, religião, etc. Os que ignoram nossa multiplicidade identitária, em favor de uma comunidade islâmica ou de qualquer outra espécie, estarão tentando criar algo que não existe de modo a expandir seu objetivo político-ideológico - neste caso, criar uma base popular de atuação engajada islamista ${ }^{145}$.(Tradução livre)

A confirmação dessa linha teórica se funda no apontamento da necessidade da inserção em uma dada comunidade para que se possa conceber a existência de direitos, bem como no fato de reconhecer que não existe apenas uma comunidade islâmica, mas várias, daí advindo as múltiplas identidades dos muçulmanos.

Sob essa perspectiva, pode se considerar que uma das funções das comunidades - islâmicas ou não - tem sido, modernamente, a de igualar os seres humanos.

Pode-se dizer que o princípio fundante para que o indivíduo venha a ser um sujeito de direitos em qualquer comunidade é a sua participação em uma dada ordem social e jurídica. Para isto, é preciso que haja uma comunidade, com atuação política, predisposta a garantir os seus direitos.

O filósofo francês Claude Lefort chama a atenção para a noção desenvolvida por Hannah Arendt de que devem ser levadas em consideração as desigualdades reais:

\footnotetext{
${ }^{145}$ CHAFIQ, Chahla. Women's rights, political islam and secularism. Weekly Worker, Londres: Communist Party of Great Britain, n. 507, p.1, ano 2003.
} 
Infelizmente, diz H. Arendt em substância, fomos constrangidos a confundir a igualdade política com igualdade social: confusão trágica pois igualdade só pode ser política; confusão que é, aliás, filosoficamente traduzida por uma idéia insensata segundo a qual os indivíduos são iguais por nascimento: a quimera dos direitos do homem. $\hat{E}^{-}$ forçoso assinalar que, para $\mathrm{H}$. Arendt, como para Burke, só são reais os direitos dos cidadãos, e os direitos do homem são uma ficção ${ }^{146}$.

Hannah Arendt elabora uma construção teórica em que os direitos humanos, da maneira como enunciados no século XVIII, trazem problemas já em sua formulação ${ }^{147}$. Essa crítica pode ser, de algum modo, transposta ao Islamismo. Nos dizeres da cientista política alemã:

A igualdade presente na esfera pública é, necessariamente, uma igualdade de desiguais que precisam $\mathrm{ser}<<$ igualados > sob certos aspectos e por motivos específicos. Assim, o fator igualador não provém da natureza humana, mas de fora, tal como o dinheiro - para retomar o exemplo de Aristóteles - é necessário como fator externo para igualar as atividades desiguais do médico e do agricultor. A igualdade política é, portanto, o oposto da igualdade perante a morte que, como destino comum de todos os homens, decorre da condição humana ou da igualdade perante Deus $[. . .]^{148}$

Deduz-se que, para a mencionada autora, são as relações estabelecidas no espaço público, entre os membros que o integram, que representam a dinâmica das características humanas. É apenas quando o indivíduo está nesse espaço que ele age confirmando sua singularidade e sua identidade. Seria somente nesse momento que ele atualizaria sua dignidade. O indivíduo sozinho, excluído da teia de relações humanas fica despido da própria dignidade humana, justamente porque nada que ele faça ou deixe de fazer terá importância.

\footnotetext{
${ }^{146}$ ARENDT, 1958 Apud LEFORT, Claude. Pensando o político: Ensaio sobre democracia, revolução e liberdade. Rio de Janeiro: Paz e Terra, 1991, p. 71.

${ }^{147}$ BRITO, Renata Romolo. Os Direitos Humanos na perspectiva de Hannah Arendt. Revista Ética e Filosofia Política. Juiz de Fora: UFJF, ano 2006, n. 01, p. 1-6.

${ }^{148}$ ARENDT, Hannah. A condição humana. Trad. Roberto Raposo. 10 ed. Rio de Janeiro: Forense, 2001, p. 35-36.
} 
Sob esse ponto de vista, a fundamentação dos direitos humanos em uma idéia de homem, abstrata e universal, como o Islam o faz, excluiria qualquer singularidade, iria de encontro à própria dignidade do ser humano.

Essa contradição entre os direitos humanos, conforme a formulação da teoria clássica (à qual a teoria islâmica é, em alguma medida, similar), e a condição humana de pluralidade ficaria aparente no caso de pessoas excluídas de suas respectivas comunidades, como é o caso das minorias religiosas. Os direitos humanos, que deveriam servir de linha-mestra para a formulação do conceito de dignidade do indivíduo, não atingiam esses grupos, cujos indivíduos sofreriam uma privação, ainda que parcial, de direitos, porque foram extirpados das teias de relações humanas.

Existem, contudo, mesmo com condições favoráveis, aspectos sociais em que o princípio da igualdade exigiria que direitos e liberdades básicos de alguns fossem limitados em prol de um maior benefício à sociedade. Nenhuma liberdade básica é, portanto, absoluta, já que em casos particulares podem entrar em conflito entre si e então suas demandas têm que se ajustar para se encaixarem num esquema coerente de direitos ${ }^{149}$.

Adentrando mais profundamente à questão, ter-se-á que se recorrer à visão de Ronald Dworkin para obter coerência lógico-argumentativa, com a aplicação do princípio ético da responsabilidade, admitindo a premissa de que a distribuição dos bens da vida, em qualquer sociedade, pode expressar, em alguma medida, as escolhas efetuadas pelos indivíduos, dado que uma distribuição que leve em conta uma isonomia absoluta e intangível não será necessariamente justa. Vê-se tal noção nas próprias palavras do autor norte-americano:

Nós assumimos responsabilidade por nossas escolhas de variadas maneiras. Quando essas escolhas são feitas livremente, e não ditadas ou manipuladas por outros, nós nos culpamos se concluímos que deveríamos ter escolhido de modo diverso. [...] Nossas circunstâncias são outra história: não faz sentido assumir responsabilidade por

\footnotetext{
${ }^{149}$ RAWLS, John. Opus citatum, p. 141-147.
} 
elas a não ser que sejam o resultado de nossas escolhas. Ao contrário, se estamos insatisfeitos com nossos recursos impessoais e não nos culpamos por nenhuma escolha que afetou nossa parcela nesses recursos, é natural que reclamemos que outros - geralmente os oficiais de nossa comunidade - foram injustos conosco. A distinção entre escolha e circunstância é não só familiar, mas fundamental em ética de primeira pessoa. [...] Não podemos planejar ou julgar nossas vidas senão pela distinção entre aquilo sobre o que devemos assumir responsabilidade, porque o escolhemos, e aquilo sobre o que não devemos porque estava além de nosso controle. ${ }^{150}$

A igualdade de acesso, em sociedade, às prestações legais básicas, apesar de ser um requisito do senso de justiça, é um dos tópicos mais controversos na modernidade. O que se observa é que quão maior for o nível de uma suposta igualdade de se atingir determinadas condições, menor será a necessidade de se explanar ou de combater as diferenças que existem entre os indivíduos e, assim, mais propícias se tornarão as condições para o estabelecimento de inequidades.

Os direitos antes tidos como imanentes à humanidade tornar-se-iam inaplicáveis, dado que tomados fora de um contexto político, ou a ele contingentes; dependendo, portanto, de uma inserção e aplicação numa dada sociedade.

A institucionalização dos direitos humanos exige um espaço público para que possa se desenvolver. O acesso a esse espaço vai se dar, ao nosso ver, justamente ao se lançar mão da utilização dos direitos subjetivos do indivíduo.

\subsection{Marco histórico da tolerância ao outro no Islam}

A despeito da possibilidade de se transpor tais críticas, a ode ao respeito que os muçulmanos guardam pela atenção à igualdade foi feito pelo filósofo iluminista Voltaire, nos seguintes temos: "Os turcos odeiam e desprezam (sic) os cristãos,

\footnotetext{
${ }^{150}$ DWORKIN, 1977 Apud MOTTA FERRAZ, Octávio Luiz. Opus citatum.
} 
os encaram como idólatras e, entretanto, os protegem em seu Império e na sua capital $^{151 "}$.

Com efeito, o primeiro exemplo de tolerância religiosa no Islam se deu com o surgimento do Estado Islâmico, por meio da sua primeira Constituição, que assegurava direitos aos cristãos e judeus que habitavam em seus territórios. ${ }^{152}$

Isto se deve, em muito, à prescrição do Alcorão, que leciona, no versículo 46 do seu capítulo XXIX, o que se segue: "E não disputeis com os adeptos do Livro, senão da melhor forma, exceto com os iníquos, dentre eles [...] nosso Deus e vosso Deus são Um e a Ele nos submetemos”.

É notório que a política dos califas frente às populações submetidas se definiu mais por vias de tolerância do que por alguma forma de coação. O sistema de pactos com os não-muçulmanos implicava uma ampla flexibilidade em variados campos, criando um regime dual na aplicação do Direito às diversas sociedades englobadas no espaço islâmico ${ }^{153}$.

Os não-muçulmanos residentes num Estado Islâmico são, em geral, denominados Povos do Tratado e gozam de todos os direitos proporcionados pelo governante, à exceção do acesso a determinados cargos públicos de mando, privativos de muçulmanos, bem como as já mencionadas restrições na esfera do Direito de Família (quanto à possibilidade de se contrair casamento com muçulmanas).

Restringe-se, ainda, a possibilidade de o não-muçulmano contrair matrimônio com a mulher muçulmana, dado que para o Islam é mandatário que os filhos sigam o Islam, sendo que os pais devem envidar esforços neste sentido. Ocorre, que, durante muito tempo, os filhos costumavam adotar a religião do pai, notadamente no Oriente Médio, onde inicialmente se desenvolveu o Islam. Eis aí a

\footnotetext{
${ }^{151}$ AROUET, François-Marie (VOLTAIRE). Essai sur les moeurs et l'esprit des nations et sur les principaux faits de l'historie depuis Charlemagne jusqu'á Louis XIII. Paris: Garnier Frères, 1963, vol. 2, p. 905.

${ }^{152}$ ISBELLE, Sami Armed. Opus citatum.

${ }^{153}$ MARTOS QUESADA, Juan. Opus citatum, 2007.
} 
justificativa de que se utilizam os teólogos islâmicos para explicar o fato de apenas o muçulmano homem poder desposar não-muçulmanas ${ }^{154}$.

Por outro lado, os indivíduos que não adotam a fé islâmica não têm obrigação de se alistar nos meios militares do Estado Islâmico, o que de outra parte, é obrigatório para todos os muçulmanos em idade adulta, dada a obrigação de defender os domínios da fé, imposta pelo Alcorão ${ }^{155}$, em caso de agressão.

Com relação aos não-muçulmanos que não são residentes no Dar al Islam, mas chegam até os domínios do Estado Islâmico, quer em viagem, quer para residir, são chamados de "os assegurados", dado que também se lhes garantem os mesmos direitos, com exceção da região da Península Arábica.

Ocorre que a presença estrangeira na região mencionada não agrada à maioria dos muçulmanos do mundo, que acreditam que existam hadices que levariam a crer que há uma vedação pela Char'ia de se permitir a permanência dos chamados infiéis ou mesmo dos ditos indivíduos dos "Povos do Livro" na área da Península Arábica. Cita-se o seguinte dito de Mohammad: "Não permanecerão duas religiões na Península Arábica”. Note-se que este é um hadice admitido como veraz, de origem confiável, tanto por sunitas como por xiitas. Não obstante isto, observa-se, inclusive, a presença militar americana no território saudita e nos Emirados Árabes Unidos, fato que parece desagradar à maioria dos muçulmanos.

Especificamente, o Islam permitiu aos não-muçulmanos que instituíssem uma vida social (legislação civil), conforme suas normas específicas como, por exemplo, quanto ao casamento, divórcio etc ${ }^{156}$, além de estender sua proteção sobre eles. Nas relações com os muçulmanos, eles se regem pelas normas da Char'ia, gozando das mesmas cláusulas de proteção gerais. Dizem, os muçulmanos, que

\footnotetext{
${ }^{154}$ Apenas as monoteístas abrâamicas: cristãs (i.E.: católicas romanas ou ortodoxas, protestantes) e judias.

${ }^{155}$ Alcorão, capítulos: II, em seus versículos 190 e 191; e IX, em seu versículo 5. In: NASR, Helmi. Opus citatum, p. 50-51 et p. 294.

${ }^{156}$ EL AED, Saleh Ibn Hussein. Opus citatum, p. 31.
} 
não há compulsão na adoção da religião ${ }^{157}$ (quanto aos não-muçulmanos).Um dos fatos que comprova o respeito dos muçulmanos aos demais se deu à época em que o Califa era o otomano Suleiman Al Kanuni que - sabendo do fato de que o muro das lamentações (parte do antigo muro do Templo do Profeta Salomão) em Jerusalém estava coberto por montes de lixo e entulho - ordenou que se retirasse o que havia sobre o muro e que se limpasse o local, permitindo aos judeus que voltassem a visitar o local ${ }^{158}$.

A esse respeito é dito no Alcorão [VI,108]: "Não injurieis os que invocam outro em vez de Allah, para que os mesmos não $\mathrm{O}$ injuriem em sua ignorância e sem conhecimento [... $]^{159 ”}$.

Com relação à afirmação de que o Islam se expandiu exclusivamente com base na ponta da espada, é de se dizer que é uma incorreção histórica.

Por sinal, os muçulmanos, antes do advento do extremismo no século XX da era cristã (sem que nos detenhamos tecendo comentários sobre os motivos que levaram ao seu surgimento), nunca se lançaram em uma empresa especificamente voltada ao ataque a certas comunidades, pelo só fato de elas professarem esta ou aquela religião, como fizeram os "cavaleiros cruzados" desde a virada do primeiro para o segundo milênio.

Em verdade, o momento em que houve uma convivência mais harmônica entre as ditas grandes religiões monoteístas (Judaísmo, Cristianismo e Islam) foi aquele da época em que se deu o domínio islâmico (mouros) na região de Al Anda$l u s^{160}$ (na atual Península Ibérica), em que se pode observar, inclusive, um esplendor da filosofia sefardí (judaica), que teve dentre os seus expoentes Maimônides

\footnotetext{
${ }^{157}$ Para os muçulmanos que abandonam o sistema de fé islâmico caberia, em tese, uma penalidade para a apostasia, o que não se tem verificado na prática nos dias de hoje, na maior parte dos países islâmicos, salvo na Península Arábica, Irã, Paquistão, Afeganistão, Indonésia e Malásia.

${ }^{158}$ EL AED, Saleh Ibn Hussein. Opus citatum, p. 27.

${ }^{159}$ NASR, Helmi. Opus citatum, p. 220.

${ }^{160}$ YAZBEK, Mustafa. A Espanha Muçulmana. 3 ed. São Paulo: Ática, 1993.
} 
(em hebraico Moshe ben Maimon - משה בן מיימון רבי), e o intenso contato entre o Cristianismo e o Islam fez com que, mais tarde, teólogos católicos como Tomás de Aquino tivessem acesso aos clássicos como Aristóteles, Platão e outros, por meio dos textos de filósofos árabes como Averróis, Avicena, Al-Ghazali etc.

A partir dos exemplos apontados resta claro que partir para definições que estereotipam as comunidades islâmicas como coletividades de fundamentalistas (termo surgido nos meios cristãos neo-pentecostais) é uma generalização absurda.

O pano de fundo de toda essa discussão reside, em última instância, na relação entre "nós" e "os outros", e na afirmação da dignidade do ser humano independente de quaisquer diferenças, seja, por exemplo, de cunho religioso, derivadas de opiniões políticas, origem social, racial ou etnia. E faz-se impossível negar que o Islam, enquanto conjunto de diretrizes de comportamento social, leva muito em consideração esta temática.

\subsection{Legado comum com o senso ocidental de igualdade}

O mito originário do Islam equivale a um protótipo in vitro de uma sociedade perfeita, mediante a qual esse sistema havia demonstrado não apenas que era capaz, não apenas de atrair inúmeras populações em regiões geográficas distintas do globo, mas também de inventar uma cultura original, diversa e digna do maior respeito. O soerguimento desse mito coletivo, na verdade um poderoso dispositivo na memória de bilhões de muçulmanos, representou e continua representando a fonte de inspiração do pensamento social e religioso que se acha na base dos movimentos de renascimento islâmico que se desencadearam no início do século XVIII e se desenvolvem com maior grau de intensidade na realidade contemporânea. Um mito que traz uma verdade em si e que foi em parte compartilhado por todos aqueles pesquisadores ocidentais (orientalistas) que exaltaram os aspectos exóticos da cultura nascida do Islam $^{161}$.

${ }^{161}$ PACE, Enzo. Sociologia do Islã: fenômenos religiosos e lógicas sociais. Trad. Ephraim Ferreira Alves. Petrópolis: Vozes, 2005, p. 236-237. 
Que a religião islâmica tenha contribuído para desenvolver a Filosofia, as Artes, a Arquitetura, a Química, a Medicina, a Astronomia, a Matemática e o Direito é fato por demais conhecido e, na inteligência de John Adams, "os fatos são coisas teimosas e quaisquer que sejam os nossos desejos, nossas inclinações, ou aquilo que dite a nossa paixão, não se poderá alterar o estado dos fatos e das evidências"162.

A afirmação deve ser, contudo, recebida com uma ressalva: não foi só o edifício religioso do sistema de crenças que estimulou a investigação racional e a criação artística. A intelectualidade islâmica logrou êxito na condução de tais tarefas porque não se opôs à contaminação com outras culturas com as quais ia deparando na medida em que expandia a sua influência.

A assim chamada idade de ouro do Islam não teria sido possível sem o encontro fecundo dos filósofos e teólogos muçulmanos com a filosofia grega (que, como se sabe, chegou à atualidade graças ao trabalho de reflexão e tradução dos pensadores árabes), sem a contribuição da cultura matemática e astronômica persa, sem a mística das culturas religiosas indianas, sem a herança da tradição oral africana e assim por diante.

Aí reside toda a extraordinária força cultural do Islam: abrir-se às outras culturas para lhes arrancar o segredo e torná-las compatíveis com o modo de pensar próprio da sua tradição ${ }^{163}$.

No dizer de Thomas Cleary:

Um dos aspectos mais conspícuos do Islam para a consciência secular cristã, por exemplo, é a inter-relação entre fé e razão. Com efeito, o Islam não demanda crença irracional. Convida, antes, à fé inteligente, ao desenvolvimento da observação, da contemplação e da reflexão, a começar por aquelas da natureza que nos circunda. Desse modo,

\footnotetext{
${ }^{162}$ ADAMS, John. Argument in Defense of the Soldiers in the Boston Massacre Trials. Boston: United States of America Office of Public Affairs and Press Releases, 1770. ${ }^{163}$ PACE, Enzo. Opus citatum, p. 237-238.
} 
o antagonismo entre religião e ciência, comum para os ocidentais, inexiste no Islam ${ }^{164}$.

O legado comum da intelectualidade islâmica e ocidental pode ser observado em diversas áreas, inclusive, naquilo que concerne ao campo do Direito. Ambas as realidades, tendo incorporado etnias, nações e culturas distintas em vastos conjuntos, inspiram aos seus pensadores o ideal de sociedades ecumênicas e a formulação de teorias correspondentes a doutrinas religiosas (Islam e Cristianismo), que historicamente desenvolveram pretensões universalistas e aspirações de se propagarem por todo o mundo ${ }^{165}$.

\section{Conclusão}

Ao longo da presente Monografia foram suscitados temas relacionados ao estudo do Direito Islâmico - Char'ia e à evolução da conceituação da igualdade no âmbito do mesmo.

Como já foi explicitado, a linha de abordagem que se seguiu neste trabalho foi a histórico-teórica, que busca compreender o seu objeto de estudo, qualquer que seja, analisando os fenômenos pelos quais passa o objeto por meio da depreensão dos conseqüentes filosóficos de sua fenomenologia

Destacamos, já no momento do projeto de pesquisa, a ligação que existe entre o autor deste estudo e a temática tratada, por questão de honestidade de princípios e dever de lealdade para com o leitor.

Isto fez com que, para além de ter verificado, in loco, como se dá a aplicação da Ciência Jurídica Islâmica, o Autor tenha podido impactar a comunidade da qual faz parte com uma visão valorativa acerca daquela dada realidade.

${ }^{164}$ CLEARY, Thomas F. O essencial do Alcorão: o coração do Islã. Trad. Pedro H. Berwick. São Paulo: Jardim dos Livros, 2008, p. 9.

${ }^{165}$ FONTOURA, Luis. Teoria Islâmica das Relações Internacionais. Revista de Direito Constitucional e Internacional, n. 54, p. 337, Ano 2006. 
Lançando vistas sobre tudo isso, saudamos o fato de que cada vez mais se perde, no âmbito das Ciências Sociais, a perspectiva de uma abstração ideal que levaria, hipoteticamente, à isenção absoluta quanto à inter-relação entre analista e objeto de análise.

Neste sentido, reputamos que se logrou êxito em defender um ponto de vista que restou inequívoco, qual seja o de que há respeito a uma noção muito peculiar de igualdade em sede de Direito Islâmico. E mais: empreendeu-se a sustentação de nossas posições sob uma perspectiva estritamente acadêmica, permitindo a um observador externo ao mundo muçulmano proceder o escrutínio de grande parte dos fenômenos legais dos Ordenamentos Jurídicos Islâmicos e percebê-los não apenas em seu caráter primordialista de bases teológicas, mas em toda a complexidade dos sistemas de nexos lógico-racionais íncitos àquele Sistema.

Resta claro que não foi a intenção do presente trabalho suscitar uma análise comparativa entre os Sistemas Jurídicos ocidentais e o islâmico; antes, o que se buscou foi apontar as diferentes abordagens acerca da conceituação da igualdade, sem, no entanto, tentar especular acerca de qual delas seja a melhor.

É notório que os sujeitos pacientes de semelhantes análises - procedidas historicamente pelo grupo de estudiosos que ficou notório pelo epíteto de "orientalistas" - objetaram, historicamente, que lhes fossem impostas leituras eurocêntricas das realidades em que se inseriam. Mas, ainda que fazendo profissão de fé quanto à necessidade de haver respeito às especificidades culturais e ideológicas islâmicas, não se pode exigir num contexto contemporâneo e globalizado que persistam civilizações estanques, que além de não assimilarem as mútuas contribuições que uma tem a dar para outra, sequer dialogam.

No primeiro capítulo recordávamos que há que se considerar que o discurso acerca de culturas pode ser entendido, em grande parte, como um reflexo do discurso relativo às religiões. Quando referimos estas, em seu aspecto institucional, estarmos nos movimentando num contexto análogo e próprio da cultu- 
$\mathrm{ra}^{166}$. Quando se faz um discurso a respeito da tolerância religiosa, pode-se partir diretamente do senso identitário das próprias religiões, mas há, também, que se procurar discernir as dinâmicas internas das instâncias culturais relacionadas com as religiões ${ }^{167}$.

Em um mundo em construção que se quer democrático e multiculturalista (não somente multicultural no sentido descritivo, mas no normativo), a abertura para o outro passa, simbolicamente, pelo reconhecimento deste em sua história. Se o Islam se encaixa num movimento monoteísta mais amplo, ele também tem, naturalmente, as suas peculiaridades que abrangem todas as esferas da vida. É uma religião, ao mesmo tempo em que é uma comunidade e um modo de viver ${ }^{168}$.

Feitas essas considerações, voltamos à perspectiva multiculturalista para afirmar que o discurso do reconhecimento conta com dois níveis: um, mínimo, em que a formação da identidade e do ser são entendidos como elementos dialógicos; e um segundo, público, em que a política do reconhecimento igualitário passou a desempenhar um papel cada vez maior.

O Islam, por exemplo, leciona que todos os homens são iguais, contudo, não são necessariamente idênticos. Assim, é natural que governassem suas atividades em harmonia com essas dissimilitudes.

A percepção da não identidade pode parecer contraditória com a afirmação da igualdade como elemento básico do dogma islâmico. No entanto, essa confusão acontece apenas devido ao uso indistinto do termo Islam para descrever uma realidade sócio-histórica e um sistema de crenças metafísicas. O Islam como dogma religioso inspira claramente uma ética igualitária: homens são iguais perante Allah. Não obstante isto, essas almas iguais são nascidas como seres humanos socialmente desiguais, com circunstâncias culturais e históricas muito diferentes.

\footnotetext{
${ }^{166}$ TERRIN, Aldo Natale. Opus citatum, p. 86.

${ }^{167}$ Ibidem, p. 338.

${ }^{168}$ VAKIL, Abdoolkarim. Opus citatum, p. 312.
} 
A noção islâmica de igualdade é o resultado de uma convenção a que os vários grupos sociais se submetem. Os mais vulneráveis a serem frustrados por outros na consecução dos seus fins ficariam em posição de exigir mais e dar menos. A igualdade será uma disposição para dar a cada pessoa aquilo que merece, de acordo com aquilo que seja a noção islâmica de justiça.

Com isto, resta respondida a primeira hipótese de pesquisa, qual seja aquela que questionava se poderíamos falar em igualdade num Direito de bases claramente teológicas. A resposta a que chegamos é afirmativa.

Assim é que passamos a destacar o modo como se procedeu à abordagem daquele que foi apontado como o objetivo geral do presente trabalho: responder ao seguinte questionamento: "como se conceitua igualdade no Islam?".

Como se viu no segundo capítulo, comentando a questão, o iraniano Hamid Enayat afirmou que a igualdade reconhecida pelo Islam, ao contrário do que ocorreu entre os gregos - que dão base à concepção ocidental do que seja isonomia - não está subordinada a quaisquer pré-condicionamentos. A igualdade para os gregos tinha apenas o significado que lhe desse a Lei; abstrato, portanto. A isonomia ali garantia igualdade não porque todos os homens fossem nascidos iguais, mas, pelo contrário, porque eram naturalmente desiguais e necessitavam de um instituto artificial, a Pólis, que pelas suas normas os igualaria, virtualmente. Para o Islam, os seres humanos são nascidos em igualdade e se tornam desiguais por razões sociais ou políticas. A igualdade para o Islam não é um atributo da Polis ou de uma região ou povo, é uma virtude inata a todos os indivíduos ${ }^{169}$.

Atentando à segunda hipótese de pesquisa, pudemos verificar que há especificidade no modo como os muçulmanos tratam a igualdade: é de se ressaltar que o seu valor não é uma mera questão de direitos ou de convenção entre particulares. Trata-se, isto sim, de um artigo de fé que o muçulmano tem de levar a sério e aderir sinceramente, como exigência da religião. Contudo, torna-se impossível falar da

${ }^{169}$ ENAYAT, 1982 Apud HOOGAR INSTITUTE. Opus citatum. 
existência de uma isonomia absoluta no ordenamento jurídico islâmico, como de resto em todos os direitos canônicos.

Existem, contudo, mesmo com condições favoráveis, aspectos sociais em que o princípio da igualdade exigiria que direitos e liberdades básicos de alguns fossem limitados em prol de um maior benefício à sociedade, como leciona John Rawls ${ }^{170}$. Nenhuma liberdade básica é, portanto, absoluta, já que em casos particulares podem entrar em conflito entre si e então suas demandas têm que se ajustar para se encaixarem num esquema coerente de direitos.

Adentrando mais profundamente à questão, recorremos à visão de Ronald Dworkin para obter coerência lógico-argumentativa, com a aplicação do princípio ético da responsabilidade, admitindo a premissa de que a distribuição dos bens da vida, em qualquer sociedade, pode expressar, em alguma medida, as escolhas efetuadas pelos indivíduos, dado que uma distribuição que leve em conta uma isonomia absoluta e intangível não será necessariamente justa. ${ }^{171}$

Em sua lapidar obra Taking rights seriously, Dworkin lembrava que o ideal abstrato da igualdade não implica necessariamente tratamento idêntico em todas as situações, mas sim o direito de ser tratado como um igual, ou seja, com o mesmo respeito e consideração que todos os demais.

Neste sentido, a relação entre os muçulmanos e os integrantes dos "Povos do Livro" é regulada por um pacto chamado dhimma. Os beneficiários desta convenção são chamados dhimmis. Os termos do acordo garantem às comunidades dhimmi segurança para seus indivíduos, direitos de propriedade, liberdade religiosa (restringindo-se o uso de símbolos externos) e um determinado grau de autonomia, em troca do reconhecimento da primazia do Islam como sistema religioso.

De acordo com a Char'ia, os dhimmis, como minoria religiosa, têm autonomia para conduzir os assuntos de suas próprias comunidades, conforme suas

\footnotetext{
${ }^{170}$ RAWLS, John. Opus citatum, p.141-147.

${ }^{171}$ DWORKIN, 1977 Apud MOTTA FERRAZ, Octávio Luiz. Opus Citatum, p. 277.
} 
leis e costumes, ao passo que, com relação ao Direito Público, estão submetidos às regulações estatais.

Naquilo que tange à igualdade de gênero, pode-se dizer que a religião islâmica considera homens e mulheres iguais quanto à essência da dignidade humana, quanto à recompensa pela conduta pessoal e aos assuntos pertinentes à moral e religião. Há controvérsia, no entanto, quanto a se as mulheres têm respeitado seu direito à igualdade em relação à sua participação na política.

Há igualdade quanto a encargos pessoais e responsabilidades comuns e, também, no pagamento por seus feitos.

Em verdade, a atitude do Alcorão e dos primeiros muçulmanos dão conta de que, como parece óbvio, para o Islam a mulher é tão vital ao desenvolvimento do mundo como o homem e de que ela não é inferior a ele. A despeito de serem consagrados tais direitos há um grande número de muçulmanos que seguem desrespeitando as normas de sua própria religião. Não fosse isso, a questão não teria despertado tanto interesse no mundo ocidental.

A mulher tem direitos e responsabilidades, na teoria islâmica clássica, assim como os homens, mas estas prestações e ônus a que fazem jus ou se submetem não são necessariamente idênticos aos dos homens. Essa diferença é inteligível, pois os homens e as mulheres são, para a doutrina religiosa em tela, distintos por natureza, mas não em essência.

Com relação à necessidade de a mulher muçulmana cobrir partes de seu corpo e quanto ao fato de isto ser observado como uma opressão com fundo em discriminação de gênero, destacamos ao fim do segundo capítulo que nos causa extremo desconforto notar que a utilização de hábitos por freiras católicas, os quais incluem véus, ou a necessidade de as mulheres judias casadas terem suas cabeças cobertas para entrar numa sinagoga ou na área do "muro das lamentações” não gera na opinião pública nenhum impulso tendente a considerar tais questões como sinais inequívocos de opressão de gênero. Contudo, quando se tratam de mulheres muçulmanas, o fato costuma gerar inquietação nas organizações feministas ao redor do mundo. 
$\mathrm{Na}$ atenção à terceira hipótese de pesquisa, podemos ressaltar que conquanto haja autores que defenderão a idéia de que somente caberia uma interpretação única, monolítica, acerca do modo como deva ser idealmente aplicado o princípio da igualdade no Islam, qual seja aquela dada pelos Tafsir (تفسير) - corrente de interpretação majoritária entre os sábios aplicada a um determinado cânone corânico - é de se dizer que optamos por seguir a técnica desenvolvida pelo filósofo muçulmano Averróis, a de opor a verdade idealmente aceita e praticada pela religião a pressupostos filosóficos e verificar se há e em que consistem as discrepâncias.

A partir da observação de quais seriam os parâmetros (aqueles postos pela religião) à aplicação do princípio da igualdade no conjunto social muçulmano é que foram feitas nossas asserções e que pudemos atestar que há, sim, uma coerência interna ao sistema de nexos lógicos desenvolvidos pelos exegetas da Char'ia naquilo que tange à aplicação do princípio da igualdade no cotidiano do Estado Islâmico.

As bases da abordagem da temática pelo Islam residem na questão de que a identificação com o Alcorão - enquanto cellula mater do Direito Islâmico - tende a apagar, como vimos, qualquer diferença de raça, cor ou status social entre os homens. Há um hadice de Mohammad que diz claramente que "Os homens são tão iguais entre si como as hastes de um tear; não haverá distinção entre o branco e o negro, entre o árabe e o não-árabe se não se quer incorrer na cólera de Allah". Aquilo que constatamos é que a comunidade islâmica segue este preceito com razoável grau de rigor e fidelidade.

\section{Equality in Islamic Law}

\section{Abstract}

The theoretical justification, that is, the exposition of the intellectual reasons that support the research, elapses the fact of being the Islam a reality each more current in the eastern world, therein enclosed Brazil. Furthermore, it is astonishing the fact that it has, today, the necessity of one to understand another, for 
the feeding of necessities asked by the multiculturalism. Considering this, as income to the academic debate, it is considered the quarrel concerning the evaluation that muslim peoples make of an institute known in the native Legal system, which is the principle of equality. One will verify the specificities as the Islamic Law treats the theme from a perspective of theological bases. It is mandatory to mention that the scientific progress echoes in the legal world, demanding the creation of new mechanisms of performance, regulation and control - being that it is verified that the present debate intends to contribute to the axiological debate and formulation in the Occidental Legal Systems, without tending to a value comparison. It shall try to avoid, as well, approaching the subject by fulffilling it in any degree, It is not to compare the Shar'ia and the standards adopted by the Occidental Legal systems, meaningfully the ones of the Roman-Germanic branch of it. What is intended, before that, is to analyze the principle of equality in the way as it is applied in the Islamic world, under the perspective of the internal logic of the studied system.

Keywords: Islam. Shar'ia. Law and Morals. Theology - social aspects. Ethics of the Religion.

\section{Referências}

ABDALATI, Hammudah. O Islam em foco. São Paulo: CDIAL, 1989.

AL-SHEHA, Abdulrahman A. Misconceptions on Human Rights in Islam. Riyadh: Escritório para propagação do Islam, 2001.

ARBEX JÚNIOR, José. Islã: um enigma de nossa época, São Paulo: Moderna, 1996.

ARENDT, Hannah. A condição humana. Trad. Roberto Raposo. 10 ed. Rio de Janeiro: Forense, 2001.

ARENDT, Hannah. As origens do totalitarismo. Trad. Roberto Raposo. São Paulo: Cia das Letras, 1989.

ATTIE FILHO, M. Falsafa: A filosofia entre os árabes - uma herança esquecida. São Paulo : Palas Athena, 2002. 
AVERRÓIS. Discurso Decisivo. Trad. Ainda Rameza Hanania. São Paulo: Editora Martins Fontes, 1994.

BANDEIRA DE MELLO, Celso Antonio. O Conteúdo Jurídico do Princípio da Igualdade. São Paulo: Malheiros Editores, 2002.

BEN AL-JAZA'IRI, Abu Bakr Jaber. The Methodology of the Muslim "Minhaj UlMuslim”, Trad. F. Amira Zrein Matraji. Beirute: Dar El Fikr, 1994.

BITTAR, Eduardo C. B. Verbete: Semiótica jurídica. BARRETTO, Vicente de Paulo. Dicionário de Filosofia do Direito. Rio de Janeiro: Editora Renovar; São Leopoldo, RS: Editora Unisinos.

BRITO, Renata Romolo. Os Direitos Humanos na perspectiva de Hannah Arendt. Revista Ética e Filosofia Política. Juiz de Fora: UFJF, ano 2006, n. 01, p. 1-6.

BULHÕES DOS SANTOS, Marcelo. Estado - Sociedade - Empreendedores: um vislumbre inovador. Brasília: 2006.

BURTON, John. An introduction to the hadith. Edinburgh: Edinburgh University Press, 1994.

CASTORIADIS, Cornelius. Encruzilhadas do Labirinto - domínios do homem. Trad. José Oscar de Almeida Marques. Rio de Janeiro: Paz e Terra, 1987.

CHAFIQ, Chahla. Women's rights, political islam and secularism. Weekly Worker, Londres: Communist Party of Great Britain, ano 2003, n. 507, p.1.

CONFERÊNCIA ISLÂMICA, Ministros de Relações Exteriores dos Países Membros da 19a. The Declaration on Human Rights in Islam. Cairo: ORGANIZAÇÃO DA CONFERÊNCIA ISLÂMICA MUNDIAL, 1990.

CONNOLY, Kate et SHENKER, Jack. The headscarf martyr: murder in German court sparks Egyptian fury. Disponível em: <http://www.guardian.co.uk/ world/2009/jul/07/german-trial-hijab-murder-egypt $\geq$. Acesso em 30 set. 2009

DA SILVA FILHO, José Carlos Moreira. Multiculturalismo e Movimentos Sociais: o privado preocupado com o público. Disponível em <http://calvados.c3sl.ufpr. br/ojs2/index.php/direito/article/viewFile/7021/4997>. Acesso: 6 out. 2008.

DAVID, René. Les grands systèmes de droit contemporains. 5 ed. Marseille: Jurisprudence Générale Dalloz, 1973. 
DEMANT, Peter. O mundo muçulmano. São Paulo: Contexto, 2004.

DE SOUZA PEREIRA, Rosalie Helena (Organizadora). Islã clássico: itinerários de uma cultura. São Paulo: Perspectiva, 2007.

DWORKIN, Ronald. Taking rights seriously. Londres: Duckworth, 1977.

EL AED, Saleh Ibn Hussein. O Direito dos não-muçulmanos sob um Governo Islâmico. Trad. Sheikh Ali M. Abdune et Prof. ${ }^{a}$ Soraia C. Mancilha. São Paulo: WAMY, 2003.

EL SAWY, Asma. O Divulgador no Islam: os métodos interpretativos da Sistemática Alcorânica. Recife: JF Gráfica, 2006.

EL SAWY SAID, Sheikh Mabrouk. Ossoulo al Feqh: A Ciência Jurídica Islâmica. Recife: JF Gráfica, 2005.

FADLULLAH, Assayed Mohammad Hussein. Nossa Mensagem I. In: ALKHAZARAJI, Sheykh Raleb Hussein. Islam a religião do diálogo. Trad. Ismail Ahmed Barbosa et Rukaia Escandar et Furqan Ali Silva. São Paulo: Centro Islâmico do Brasil, 2007.

FOMMENTI, Monsignor Vittorio. Annuario Pontifício 2008. Cidade do Vaticano: Libreria Editrice Vaticana, 2008.

FONTOURA, Luis. Teoria Islâmica das Relações Internacionais. Revista de Direito Constitucional e Internacional. Ano 2006, n. 54

GARCÍA CRUZ, Jose Fernando, Un análisis del derecho islâmico, Cáceres: Universidad de Estremadura, Servicio de Publicaciones, 2004.

GILISSEN, John. Introdução Histórica ao Direito. 3 ed. Lisboa: Fundação Calouste Gulbenkian, 2001.

HAMID, Shadi An Islamic Alternative? Equality, Redistributive Justice, and the Welfare State in the Caliphate of 'Umar. Disponível em: <http://www.renaissance. com.pk/Augvipo2y3.html> Acesso em 20 out. 2008.

HOOGAR INSTITUTE. Enayat on Islam and Democracy. Disponível em: < http://www.hoggar.org/index.php?option=com_docman\&task=doc_ download\&gid=158\&Itemid=28>. Aceso em : 3 jun. 2009. 
HOURANI, Albert Habib. A history of the arab peoples, Oxfordshire: Orxford University Press, 1991.

ISBELLE, Sami Armed. O Estado Islâmico e sua Organização. Rio de Janeiro: Qualitymark, 2007.

JAHANBAKHSH, Forough. Islam, Democracy and Religious Modernism in Iran. Boston: Brill, 2001.

JOMIER, Jacques. Islamismo: História e Doutrina. Trad. Luiz João Baraúna. Petrópolis: Vozes, 1992.

KAMALI, Mohammad Hashim. Freedom, Equality and Justice in Islam. Islamic Texts Society: Cambridge, 2002.

KAMALI, Mohammad Hashim. Principles of Islamic Jurisprudence. Islamic Texts Society: Cambridge, 2003.

KAMEL, Ali. Sobre o Islã: afinidade entre muçulmanos, judeus e cristãos e as origens do terrorismo. Rio de Janeiro: Nova Fronteira, 2007.

LEFORT, Claude. Pensando o político: Ensaio sobre democracia, revolução e liberdade. Rio de Janeiro: Paz e Terra, 1991.

LEWIS, Bernard. The political language of Islam. Chicago: The University of Chicago Press, 1988.

MACINTYRE, Alasdair. Justiça de quem? Qual racionalidade?. Trad. Marcele Pimenta Marques. São Paulo: Loyola, 1991.

MAHÁIRI, Ahmed Saleh. Programa de pregação às minorias muçulmanas. Brasília: Embaixada Real da Arábia Saudita no Brasil, 1985.

MARTOS QUESADA, Juan. “O Direito Islâmico Medieval”. In: PEREIRA, Rosalie Helena de Souza (org.). O Islã clássico: itinerários de uma cultura. São Paulo: Perspectiva, 2007.

MOTTA FERRAZ, Octávio Luiz. Justiça Distributiva para formigas e cigarras. Disponível em: < www.cebrap.org.br/imagens/Arquivos/critica01 ferraz.pdf $>$. Aceso em: 22 set. 2009. 
NASR, Helmi. Tradução do sentido do Nobre Alcorão para a língua portuguesa. Medina: Complexo do Rei Fahd, 2005.

NOUFOURI, Sumer. La Dignidad de la Persona Humana en el Islam. Disponível em: <http://www.revistapersona.com.ar/sumer.htm>. Acesso em: 6 set. 2008.

NUJAYM, Ibn. Tratado de direito sobre as similitudes e semelhanças. Cairo: 1592.

PACE, Enzo. Sociologia do Islã: fenômenos religiosos e lógicas sociais. Trad. Ephraim Ferreira Alves. Petrópolis: Vozes, 2005.

RAWLS, John. Justiça como eqüidade: uma reformulação. Trad. Claudia Berliner. São Paulo: Martins Fontes, 2003

SIEGMAN, H. The State of individual in sunni Islam. The Muslim World. Hartford: Blackwell Publishing, ano 1964, n. 54, p. 188-195.

SOARES, Marina Juliana de Oliveira. Traços de racionalismo oriental: os estudos de weber sobre o islã. Revista Travessias, Cascavel: Universidade Estadual do Oeste do Paraná, ano 2005, n. 1, p. 8-9.

TAYLOR, Charles. Multiculturalismo. Lisboa: Piaget, 1998.

TERRIN, Aldo Natale. Antropologia e horizontes do sagrado: cultura e religiões. São Paulo: Paulus, 2004.

ÚRSULA ETTNUELLER, Eliane. Islam and Democracy. Disponível em: <http:// www.ub.es/astrolabio/articulos3/ARTICULOEliane.pdf> Acesso em 29 ago. 2008.

VAKIL, Abdoolkarim. Do outro ao Diverso - Islão e Muçulmanos em Portugal: história, discursos, identidades. Revista Lusófona de Ciência das Religiões, Lisboa: Edições Universitárias Lusófonas, ano 2004, n. 05, p. 283-312.

YAZBEK, Mustafa. A Espanha Muçulmana. 3 ed. São Paulo: Ática, 1993.

ZAIDAN, Abdul Karim. O Indivíduo e o Estado no Islam. São Paulo: Centro de Divulgação do Islam para a América Latina, 1990. 


\section{Apêndice A}

Entrevista realizada com o Sheykh MABROUK EL SAWY SAID, Doutor em Chariah pela Universidade Islâmica de Al-Azhar - Cairo, na República Árabe do Egito, sendo autor de diversas publicações (livros e artigos) acadêmicos sobre a doutrina islâmica e exercendo as funções de Imam no Centro Islâmico do Recife, como Sheykh acreditado pela Liga Islâmica Mundial, desde o ano de 1992.

Os questionamentos foram realizados no Centro Islâmico do Brasil (Brasília/DF), aos 10 de junho de 2009, tendo havido a expressa anuência do entrevistado em que se utilizasse este excerto no presente Trabalho monográfico.

$\underline{1-M B S}$ - O que é o Princípio da Igualdade para o Islam?

Sh. Mabrouk - Refere-se ao termo Al Musāwāt, relativo ao conceito introduzido pelo Al Quran em sua sura (capítulo) de número XLIX, 13.

$\underline{2-M B S}$ - Como se dá a relação de proteção para com as minorias religiosas?

Sh. Mabrouk - Depende. Temos que distinguir o Ahl Kitab, ou Povos do Livro, dos Al Káffirun, ou Idólatras. Com relação aos integrantes dos Ahl Kitab - ou seja, judeus e cristãos - quando estão sob o Estado Islâmico passam a ser chamados de Ahl al Dhima, como aconteceu na cidade de Medina, após a constituição do Estado Islâmico, no ano I da Hégira.

$\underline{3-M B S}-E$ isso levou a que construção?

Sh. Mabrouk - à construção da idéia de Ahl al Dhima, ou seja, de que o Povo do Tratado deve ser protegido nos termos que se obriga.

$\underline{4-M B S}$ - Qual a influência dos místicos no Islam?

Sh. Mabrouk - São os sufis, que podem ser divididos, didaticamente, nos de $1^{\text {a }}$ geração (que se concentraram até o fim do século III pós-hégira) e $2^{a}$ geração. Os primeiros tiveram influência sobre a Char'ia e, mais especificamente, sobre as questões atinentes ao ibadah, ou seja, aos ritos devocionais, fazendo especial menção à necessidade de seguir o Quran, os Hadice (sunna), dedicavam-se ao estudo da distinção entre aquilo que é Halal (permitido) e o que é Haram (proibido).

$\underline{5-M B S}$ - Como se dividiu modo de se aplicar as normas e princípios da hermenêutica à Lei revelada? 
Sh. Mabrouk - As principais Escolas Islâmicas de interpretação das fontes da Char'ia foram a Malikita, a Chafita,a Hanbalita e a Hanifita, ao lado da Escola Jafarita, sendo que esta última era xiita.

$\underline{6-M B S}$ - Qual a composição do total de muçulmanos brasileiros com relação à adesão às Escolas dentro do Islam?

Sh. Mabrouk - Como no mundo, aqui os sunitas são maioria. No entanto, a desproporção aqui parece ser menor. No Sul do país, por exemplo, notadamente no Paraná e em Santa Catarina, os xiitas são maioria. Além desses dois grupos majoritários, há grupos menores de seguidores das linhas Alawita, Ahmadia e da fé $B a h a^{\prime} i$, que também se dizem muçulmanos, apesar de não serem vistos desta forma pelos demais irmãos.

$\underline{7-M B S}$ - E o que dizer do versículo 62 da segunda sura do Al Qur'an ${ }^{172}$ ?

Sh. Mabrouk - Esse versículo só se aplica aos que sigam de fato os seus respectivos profetas.

$\underline{8-M B S}-$ Qual é a principal diferença doutrinária entre a maioria sunita e a minoria xiita?

Sh. Mabrouk - Sob o ponto de vista teológico, a diferença fundamental se refere à doutrina do imamato, advogada pelos xiitas e refutada pelos sunitas, os quais reputam não haver superioriade de um muçulmano em relação a outro pelo só fato de ele descender ou não de um profeta, ao contrário dos primeiros. Sob a perspectiva normativa há, também, algumas diferenças entre a Escola Jafaria (xiita) e as demais, como a permissão do casamento temporário, que para a ortodoxia sunita é algo ilícito.

9-MBS - Como se deu a entrada dos muçulmanos no Brasil?

Sh. Mabrouk - Em 1871 começaram a chegar as primeiras levas de árabes por aqui, mas nessa época a maioria era de católicos ortodoxos (maronitas) sírio-libaneses. Foi após a segunda guerra mundial e a implantação do Estado Judeu na Palestina que começaram a chegar as grandes levas de muçulmanos, vindos do sul do Líbano, Palestina, Síria e Egito. Após a década de 80, começaram a chegar os muçulmanos da África negra.

${ }^{172}$ Qur'an II, 62: Os que crêem e os que abraçaram o judaísmo e os cristãos e os sabeus, todos os que crêem em Deus e no último dia e praticam o bem obterão sua recompensa de Deus e nada terão a recear e não se entristecerão. 
U84 Univ. JUS, Brasília, v. 22, n.1, p. 407-484, jan./jun. 2011
Marcelo Bulhões dos Santos

10 - MBS - Quais as linhas abordadas pela Char'ia?

$\underline{S h}$. Mabrouk - Um pouco de tudo... Desde o Direito material até o processual. Fala-se do Direito Civil, Penal, "Canônico”, Comercial, Família e Sucessões, dentre outros. 